\title{
Electroporation in Biological Cell and Tissue: An Overview
}

\author{
Maša Kandušer and Damijan Miklavčič
}

\begin{abstract}
In this chapter, basics and mechanisms of electroporation are presented. Most important electric pulse parameters for electroporation efficiency for different applications that involve introduction of small molecules and macromolecules into the cell or cell membrane electrofusion are described. In all these applications, cell viability has to be preserved. However, in some biotechnological applications, such as liquid food sterilization or water treatment, electroporation is used as a method for efficient cell killing. For all the applications mentioned above, besides electric pulse parameters, other factors, such as electroporation medium composition and osmotic pressure, play significant roles in electroporation effectiveness. For controlled use of the method in all applications, the basic mechanisms of electroporation need to be known. The phenomenon was studied from the single-cell level and dense cell suspension that represents a simplified homogenous tissue model, to complex biological tissues. In the latter, different cell types and electric conductivity that change during the course of electric pulse application can significantly affect the effectiveness of the treatment. For such a complex situation, the design and use of suitable electrodes and theoretical modeling of electric field distribution within the tissue are essential. Electroporation as a universal method applicable to different cell types is used for different purposes. In medicine it is used for electrochemotherapy and genetherapy. In biotechnology it is used for water and liquid food sterilization and for transfection of bacteria, yeast, plant protoplast, and intact plant tissue. Understanding the phenomenon of electroporation, its mechanisms and optimization of all the parameters that affect electroporation is a prerequisite for successful treatment. In addition to the parameters mentioned above, different biological characteristics of treated cell affect the outcome of the treatment. Electroporation, gene electrotransfer and electrofusion are affected by cell membrane fluidity, cytoskeleton, and the presence of the cell wall in bacteria yeast and plant cells. Thus, electroporation parameters need to be specifically optimized for different cell types.
\end{abstract}

\footnotetext{
M. Kandušer

Faculty of Electrical Engineering, University of Ljubljana, Tržaška 25, SI-1000 Ljubljana, Slovenia e-mail: Masa.Kanduser@fe.uni-lj.si
} 


\section{Basics and Mechanisms}

Electroporation is a method of cell membrane permeabilization that is today widely used in biotechnology and medicine for delivery of drugs and genes into living cells (Neumann et al. 1982; Fromm et al. 1985; Teissié 1988; Ferber 2001; Prud'Homme et al. 2006). It is alternative method for water sterilization and food preservation (Teissié et al. 2002), and it is a prerequisite for cell electrofusion (Zimmermann 1982; Teissié and Rols 1986; Ramos and Teissié 2000a).

The phenomenon of electroporation can be described as a dramatic increase in membrane permeability caused by externally applied short and intense electric pulses. Various theoretical models were developed to describe electroporation, among which the transient aqueous pore model is the most widely accepted. According to this model, hydrophilic pores are formed in the lipid bilayer of a cell membrane when it is exposed to external electric pulses. In the cell membrane, hydrophobic pores are formed by spontaneous thermal fluctuations of membrane lipids. In a cell exposed to an external electric field, the presence of an induced transmembrane potential provides the free energy necessary for structural rearrangements of membrane phospholipids and thus enables hydrophilic pore formation (Neumann et al. 1989; Tsong 1991; Chang et al. 1992; Weaver and Chizmadzev 1996). Hydrophilic pores form only in a small fraction of the membrane exposed to electric field. Even though some attempts to visualize the changes in the membrane structure caused by electric pulse application were made (Stenger and Hui 1986; Chang and Rees 1990), the structural reorganization and creation of hydrophilic pores has so far not been directly observed (Rols 2006). All the data available until now have been obtained as an indirect evidence of membrane permeabilization, such as measurements of conductivity changes caused by electric pulse application and observations of molecular transport through the cell membrane (Neumann et al. 1989; Weaver and Chizmadzev 1996).

Cell membrane electroporation takes place because the cell membrane amplifies the applied external electric field, as its conductivity is several orders of magnitude lower than the conductivities of extra cellular medium and cell cytoplasm. The theoretical description of the transmembrane potential induced on a spherical cell exposed to electric field is known as Schwan's equation (Neumann et al. 1989; Marszalek et al. 1990; Kotnik et al. 1997). The induced transmembrane potential for a spherical cell can be calculated as:

$$
\mathrm{U}_{\mathrm{TI}}=-1.5 \mathrm{rEcos} \varphi
$$

where $r$ is the radius of the cell, $E$ is the strength of applied electric field, and $\varphi$ is the angle between the direction of the electric field and the selected point on the cell surface. The induced transmembrane potential and therefore maximum electroporation occur at the poles of the cell exposed to the electric field facing the electrodes (Fig. 1).

Electroporation can be either reversible or irreversible, depending on parameters of the electric pulses. It is a threshold phenomenon: the induced transmembrane 
Fig. 1 Cell in an electric

field. The induced

transmembrane potential is

maximal at the poles of the

cell in accordance with

Equation (1). Electroporated

area is presented with dashed

line

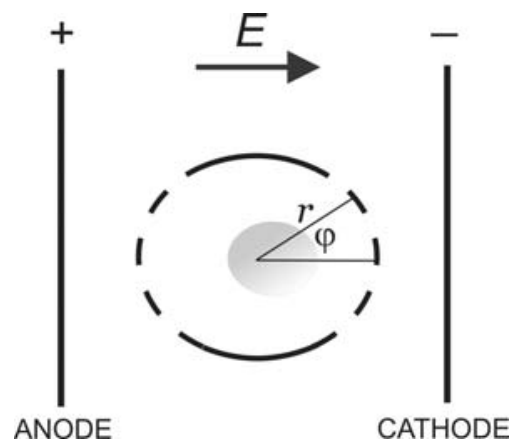

voltage imposed by external electric field should reach a critical value to trigger formation of transient aqueous pores in the cell membrane (Kinosita and Tsong 1979; Abidor et al. 1979; Neumann and Rosenheck 1972; Kinosita and Tsong 1977). The threshold membrane potential that needs to be reached in the cell membrane is between $200 \mathrm{mV}$ and $1 \mathrm{~V}$ (Zimmermann 1982; Tsong 1991; Teissié and Rols 1993). For reversibility of electroporation, the membrane potential has to be kept below the critical value. In such conditions, the cell membrane recovers after electric pulse application (Neumann et al. 1989). On the contrary, when the critical value is exceeded, irreversible electroporation takes place, resulting in cell membrane disintegration and loss of cell viability (Hamilton and Sale 1967; Meaking et al. 1995; Danfelter et al. 1998).

The electroporation process consists of different phases. The first of them is pore formation, which is the cell membrane's response to the induced threshold membrane potential, and lasts a few microseconds. The second phase is a timedependent expansion of the pore size taking place in a time range of hundreds of microseconds to milliseconds, and lasts throughout the duration of pulses. The last phase is membrane recovery, which takes place after electric pulse application and consists of pore resealing, and lasts several minutes (Kinosita and Tsong 1977; Hibino et al. 1993; Neumann et al. 1999; Leontiadou et al. 2004). This resealing phase is strongly affected by temperature (Kinosita and Tsong 1977) and cytoskeleton integrity (Rols and Teissié 1992a; Teissié and Rols 1994). The first phase of electroporation can be measured by changes in membrane conductivity and is related to short-lived transient pore formation, which does not contribute to molecular transport (Pavlin et al. 2007). Molecular transport across the permeabilized cell membrane associated with electroporation is observed from the pore formation phase until membrane resealing is completed (Gabriel and Teissié 1997, 1999; Prausnitz et al. 1995; Puc et al. 2003; Pavlin et al. 2007).

Electroporated membranes are also a prerequisite for associated membrane phenomena termed electrofusion. During electric pulse application and immediately after it, the cell membrane is capable of fusion: it is in a so-called fusogenic state (Teissié et al. 1982; Zimmermann 1982).

In brief, electroporation is a useful technique in biotechnology and medicine for introduction of different molecules into the cell, electrofusion, or water sterilization 
and food preservation. Among different theoretical models that describe electroporation, the transient aqueous pore model is most widely accepted. This model predicts hydrophilic pore formation as a response to induced external electric field on the cell membrane. Electroporation can be reversible or irreversible, depending on the electric pulse parameters used.

\section{Influential Parameters}

Electroporation is affected on the one hand by parameters of electric pulses and chemical composition of the media used and on the other by the characteristics of the cell that is exposed to the electric field. The effect of the electric pulse parameters and electroporation media are described in this section.

\subsection{Parameters of Electric Field}

The parameters of electric pulses were extensively investigated. The most important electric pulse parameters are amplitude, duration, number, and repetition frequency (Rols and Teissié 1990a; Wolf et al. 1994; Gabriel and Teissié 1995a; Vernhes et al. 1999; Maček-Lebar et al. 1998; Maček-Lebar and Miklavčič 2001; Bilska et al. 2000; Canatella et al. 2001). If those parameters exceed the optimal values, irreversible electroporation takes place due to cell membrane disintegration (Hamilton and Sale 1967; Danfelter et al. 1998) and DNA damage (Meaking et al. 1995), resulting in cell lysis. The choice of electric pulse parameters thus depends on the desired application. Some applications require reversible, while others require irreversible electroporation. For loading of foreign molecules into the cell, reversible electroporation is required. The choice of electric pulse parameters depends on the type of the foreign molecule that is being introduced. For small molecules, such as different drugs or fluorescence dyes, a train of relatively short pulses (time duration in range of microseconds to milliseconds) is sufficient. For large molecules, such as DNA, longer pulses (range of few milliseconds) or a combination of high-voltage short-duration pulses and low-voltage long-duration pulses is used (Wolf et al. 1994; Klenchin et al. 1991; Sukharev et al. 1992; Šatkauskas et al. 2002).

Besides the before mentioned parameters of electric pulses, different pulse shapes can also be used. The most frequently used are exponential and square wave pulses. One should be careful when comparing results obtained by different pulse shapes, as the membrane polarization process that takes place during the pulse application is different (Neumann 1992).

Electric pulses can be applied in one direction or their orientations can be changed during the pulse application. Such protocols were successfully used for electrochemotherapy and gene electrotransfer (Rols, Teissié 1990a; Tekle et al. 1991; Serša et al. 1996; Vernhes et al. 1999; Kotnik et al. 2001a; Kotnik et al. 2001b; Golzio et al. 2002; Faurie et al. 2004; Faurie et al. 2005; Reberšek et al. 2007). 


\subsubsection{Introduction of Small Molecules}

For introduction of small molecules, short electric pulses in a range of tens to hundreds of microseconds are generally used. The most important parameter is pulse amplitude. It should reach a threshold value at which the electroporation of cell membrane is triggered. Above the threshold value the increase in electroporation is obtained with increase of pulse duration and number of pulses (Fig. 2). The increase in pulse duration increases the electroporation of cells until a plateau is reached and further increase in number of pulses or its duration does not affect cell electroporation (Rols and Teissié 1990a; et al. 1993; Maček-Lebar and Miklavčič 2001). At the same time the increase in pulse number and pulse duration affects cell viability (Gabriel and Teissié 1995b; Maček-Lebar and Miklavčič 2001). The following explanation for the relationship between the pulse amplitude and the pulse number or duration was proposed: increasing the pulse amplitude results in larger area of membrane electroporation with smaller extent of electroporation, while increase in pulse number or duration does not affect the electroporated membrane area but increases the extent of electroporation (Fig. 3) (Rols 2006). Nevertheless, when increasing the duration of the pulse, one should also consider that longer pulses cause significant Joule heating of the sample (Pliquett et al. 1996).

Systematic study of electric pulse parameters revealed that electroporation and cell viability are not related to the total electrical energy delivered (Maček-Lebar et al. 1998; Vernhes et al. 1999). Further examinations of different parameters of electric pulses indicate complex dependence between electric pulse parameters and degree of electroporated cell membrane (Canatella et al. 2001).

Another electric pulse parameter affecting electroporation of the cell membrane is pulse repetition frequency. When pulses are applied with high repetition frequency, above $1 \mathrm{kHz}$, the pause between two consecutive pulses is too short and does not allow cell membrane to return to pre-pulse state. From the experimental results it can be concluded that cell viability and cell membrane electroporation is optimal in the frequency range from 0.5 to $10 \mathrm{~Hz}$ and decreases at higher frequencies (Vernhes et al. 1999; Pucihar et al. 2002; Pavlin et al. 2005).

Fig. 2 Fraction of electroporated cells is increasing with increasing number of applied pulses. E, electric field strength, $\mathrm{T}$, pulse duration, $\mathrm{N}$, number of applied pulses

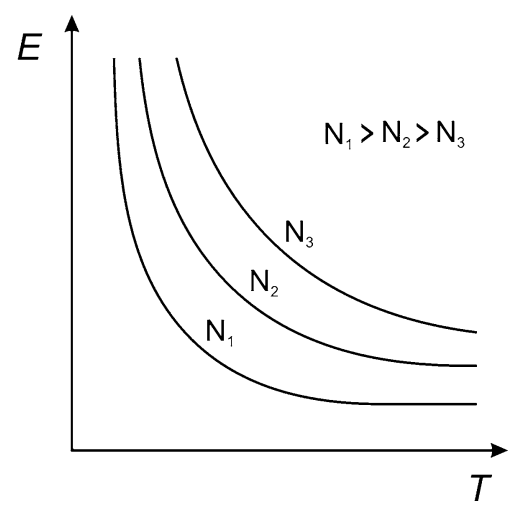




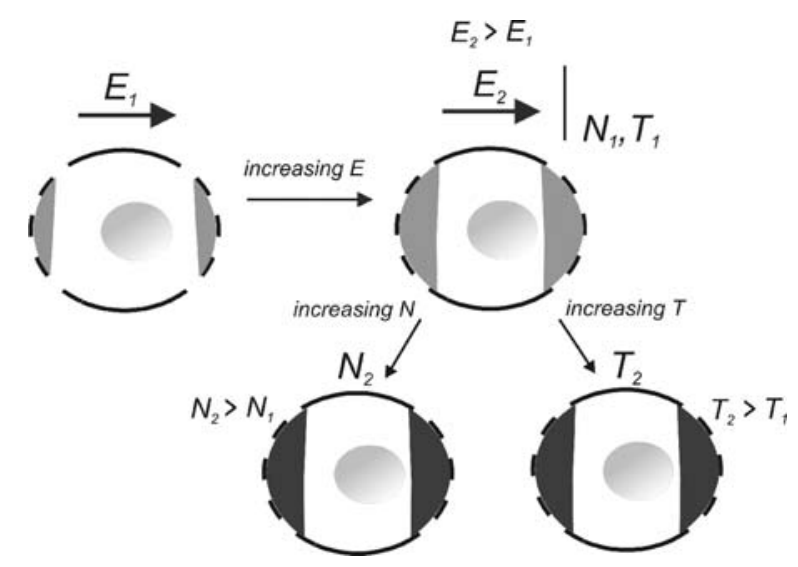

Fig. 3 Increasing the pulse amplitude results in larger area of membrane with smaller extent of electroporation, while increase in pulse number or duration does not affect the membrane area but increases the extent of electroporation

For reversibility of electroporation, the membrane potential has to be kept below the critical value. In such conditions, the cell membrane recovers after the electric pulse application (Neumann et al. 1989). On the contrary, when critical value is exceeded, irreversible electroporation takes place, resulting in cell membrane disintegration and loss of cell viability (Hamilton and Sale 1967; Meaking et al. 1995; Danfelter et al. 1998).

\subsubsection{Introduction of Macromolecules}

The optimal conditions for introduction of macromolecules are different from optimal conditions for introduction of small molecules (Wolf et al. 1994). Most experiments were performed with long, 5 to $10 \mathrm{~ms}$ pulses with relatively low pulse amplitude. When those results were compared with results obtained with highervoltage microsecond pulses, typically used for introduction of small molecules, it was established that many different pulse parameters are capable of delivering plasmid DNA into the cell. Protocols employing millisecond pulses are more efficient than microsecond pulses for long-term gene expression in vivo (Lucas and Heller 2001).

The efficiency of gene electrotransfer into mammalian cells was first related to the pulse shape used, and exponentially decaying pulses were reported as more effective that the square wave pulses (Andreson and Evans 1989). Later, the use of combination of high-voltage and low-voltage pulses was suggested. High-voltage pulse causes electroporation of cell membrane, while the low-voltage pulse helps highly charged DNA entrance into the cell interior. A low-voltage pulse thus provides electrophoretic movement of DNA into the cell in in vitro conditions, or it can be a powerful driving force for improving interstitial transport of DNA during gene delivery in vivo (Klenchin et al. 1991, Sukharev et al. 1992; Zaharoff 
et al. 2002; Zaharoff and Yuan 2004). The effect of electrophoretic pulses was successfully used and demonstrated in in vivo experiments in mammalian tissues (Bureau et al. 2000; Somiari et al. 2000; Šatkauskas et al. 2002; Šatkauskas et al. 2005; Andre and Mir 2004; Zampaglione et al. 2005; Pavšelj and Preat 2005a). Nevertheless, the role of electrophoretic force in DNA movement across permeabilized membrane is questioned for in vitro gene electrotransfer as no contribution of electrophoretic force could be detected (Wolf et al. 1994). Lately the effect of electrophoretic movement of DNA by low-voltage pulse has also been questioned for in vivo applications (Liu et al. 2006).

The effect of low-voltage electric pulse on the highly charged DNA is alternatively attributed to electrophoretic accumulation of DNA on the cell membrane (Wolf et al. 1994). It has also been demonstrated by visualization of DNA interaction with the cell membrane that the electric field orientation plays an important role in gene electrotransfer (Golzio et al. 2002; Faurie et al. 2004; Faurie et al. 2005; Reberšek et al. 2007). Similar to small molecules, asymmetric DNA uptake is observed during electroporation (Mehrle et al. 1985; Tekle et al. 1991). Nevertheless, DNA, unlike small molecules that enter cell cytoplasm on the membrane-facing cathode, enters the cell on the surface-facing anode (Golzio et al. 2002; Faurie et al. 2004; Faurie et al. 2005). Another main difference between introduction of small molecules and DNA is that for successful gene electrotransfer, DNA has to be present in the medium before electric pulses are applied (Fig. 4) and the transport of the DNA through cell membrane takes place minutes after the pulse

A.

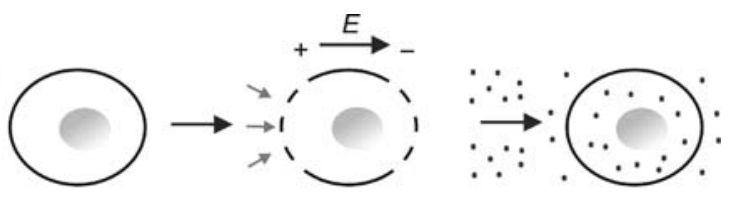

B.

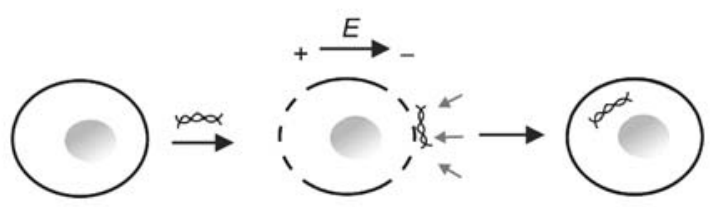

c.

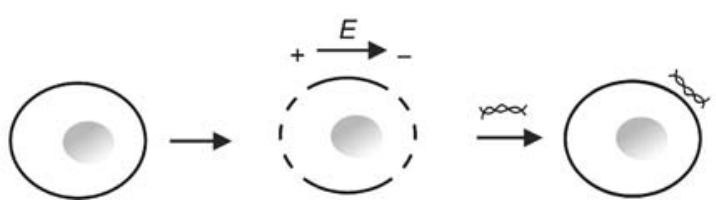

Fig. 4 Introduction of small and large molecules by electroporation. (A) Introduction of small molecules takes place during and predominantly after the pulse. Electroporation of the cell membrane is asymmetrical and occurs first at the anode side (small grey arrows). (B) Introduction of DNA into the cell. DNA must be present before electric pulses are applied. The initial step is DNA adsorbtion to the cell membrane, which takes place in the cell membrane facing cathode (small grey arrows). (C) When DNA is added after the pulse application it cannot be introduced into the cell 
application (Golzio et al. 2002). No spontaneous interaction of DNA with the cell membrane was detected. The complex between the DNA and the membrane forms only when the membrane is electroporated. If DNA is added after pulse application, no transfection can be observed. It was, however, demonstrated that transfection is successful if the DNA is added after the high-voltage pulse and before low-voltage pulse, but the level of DNA expression is lower (Šatkauskas et al. 2002).

\subsubsection{Electrofusion}

The electrofusion is a two-step process; it involves cell membrane electroporation and a close physical contact of two electroporated membranes in fusogenic state (Zimmermann 1982; Saunders et al. 1986). The electric field parameters needed for introduction of small molecules and for electrofusion are similar. The main difference between two processes is the critical voltage required for electrofusion, which is higher than for electroporation (Teissié and Rols 1993; Abidor et al. 1994; Teissié and Ramos 1998), and the duration of fusogenic state, which is shorter than cell membrane resealing process. The resealing of the cell membrane after electroporation can take up to tens of minutes, while membrane fusion is only possible if the contact of permeabilized membranes is achieved within few minutes after pulse application (Teissié and Rols 1986; Sowers 1986; Ramos and Teissié 2000a). The contact needed for electrofusion can be obtained before or immediately after the electroporation pulse. When the cell contact is obtained before electroporation, most often dielectrophoresis is used (Zimmermann 1982), while the contact of cells after electroporation is obtained by centrifugation of fusogenic cells (Teissié and Rols 1986; Sowers 1986).

The close physical contact obtained by dielectrophoresis results in pearl chain formation (Zimmermann 1982). For this application, an alternating electric field of low amplitude on the order of few hundred volts per centimeter and frequencies in the range of $10 \mathrm{kHz}$ to $6 \mathrm{MHz}$ is used (Zimmermann 1982; Vienken and Zimmermann 1985; Saunders et al. 1986). During electrophoresis the polarized cells are attracted to the areas of high field strength (Oblak et al. 2007). Cells migrate toward each other and form pearl chains. The procedure is rapid and has negligible effect on cell viability (Saunders et al. 1986). The alternating electric field is then switched off and an electroporation pulse is applied. To maintain cells in the close contact after electroporation, the alternating electric field is applied again for a short duration (Vienken, Zimmermann 1985).

When the contact of electroporated cells is obtained after the pulse (Teissie and Rols 1986), better fusion yield is obtained, if a larger membrane area is in fusogenic state. This can be obtained by proper selection of electric pulse parameters, such as number of pulses and their duration (Ramos and Teissié 2000a). When the electric field orientation is changed during the pulse application, it results in increase of electroporated area of cell membrane (Valič et al. 2003). The efficiency of electrofusion was reported to be slightly lower when the contact is obtained after the pulse than with the pre-pulse contact (Wu et al. 1992). Therefore, it is possible that 
the membrane merging already starts during the electric pulse application and is concluded after the pulse (Dimitrov and Sowers 1990).

Besides electric field parameters, mechanical forces can increase the fusion yield as they enable good contact of cells (Jaroszeski et al. 1994; Ramos and Teissié 2000b).

\subsubsection{Irreversible Electroporation}

Irreversible electroporation is in some applications the undesired, while in others it is the desired outcome of the electric pulse application. It is a consequence of membrane rupture that is a directly caused by electric pulse application (Weaver and Chizmadzev 1996). Irreversible electroporation and Joule heating are an integral part of electrical injury, which affects especially nerve and muscle cells due to their size. Release of intracellular components from affected cells cause acute renal failure due to deposition of iron-containing molecules such as myoglobin (Lee and Dougherty 2003). Successful treatment of electroporated membranes with nontoxic polymers can reduce tissue injury produced by irreversible electroporation due to sealing of electroporated cell membranes (Lee et al. 1992; Lee and Dougherty 2003).

Irreversible electroporation is the desired result when it is used for microbial deactivation in water and food treatment. The applied electric pulses should cause irreversible damage of treated cells (Teissié et al. 2002). For effective treatment, critical electric field parameters should be chosen properly. Typical pulse amplitude for microbial deactivation in water and liquid food is between 20 and $35 \mathrm{kV} / \mathrm{cm}$, pulse duration, from micro- to milliseconds, and pulse number varies from ten to hundred pulses (Zhang et al. 1995; Angersbach et al. 2000; Beveridge et al. 2002). For food preservation, amplitudes used are lower than for microbial inactivation in freshwater and liquid food. The main problem is the choice of optimal treatment parameters that would require minimal power consumption and would effectively disintegrate treated cells (Lebovka et al. 2000, 2002).

Recently, irreversible electroporation was reported as an alternative minimally invasive surgical technique in medicine for tissue ablation. The train of ten electrical pulses in the range of $1.5 \mathrm{kV} / \mathrm{cm}$ and duration $300 \mathrm{~ms}$ was applied three times for effective tissue ablation. The method was also tested in vivo. For in vivo applications, mathematical models provided a valuable tool for proper electrode positioning and optimal pulse parameter determination for effective treatment (Davalos et al. 2005; Miller et al. 2005; Edd et al. 2006; Rubinsky et al. 2007).

\subsection{Electroporation Medium Composition}

Conflicting reports are found on the effect of medium composition on electroporation. In some reports, increasing the ionic strength of the medium resulted in cell membrane electroporation at lower electric field intensities. The nature of monovalent ions such as sodium, potassium, or lithium $(\mathrm{Na}, \mathrm{K}, \mathrm{Li})$ does not affect the 
electroporation. On the other hand, presence of bivalent calcium ion in the medium resulted in cell lysis and death (Rols and Teissié 1989). Nevertheless, toxicity of calcium ions was reported independently of electroporation, as they are involved in different physiological processes in the living cell. Because of sudden and uncontrolled increase of calcium in the cytoplasm, the cell cytoskeleton is disrupted and uncontrolled activation of calcium-dependent catabolic enzymes takes place (Orrenius et al. 1989).

In some studies, when the medium conductivity was maintained unchanged, the effect of ionic composition and strength of the media on electroporation was almost negligible. Yet, when medium conductivity was decreased, electroporation efficiency increased drastically. In contrast, the resealing of the membrane was independent on medium ionic composition or conductivity (Djuzenova et al. 1996; Barrau et al. 2004). In our study performed in the wide range of medium conductivities it was observed that cell membrane electroporation as such was not affected by medium conductivity, while it had significant effect on cell survival (Pucihar et al. 2001). Medium composition affects heating of the sample during electroporation. When short electric pulses are used (in range of microseconds), Joule heating in high-conductivity media is negligible. On the other hand, when long pulse duration (milliseconds) and high amplitudes are used, Joule heating takes place during electroporation and is more pronounced in high-conductivity than in low-conductivity media (Pliquett et al. 1996; Pavlin et al. 2005).

Medium composition plays an even more important role in gene electrotransfer of bacteria, yeast, plant, and animal cells. Monovalent alkali ions were found to be involved in gene electrotransfer of the plant protoplasts. It was proposed that they increase membrane fluidity or enhance membrane electrical potential, making the protoplast more susceptible to an applied electric pulse (Saunders et al. 1989). In contradiction to the previously reported role of calcium on cell viability, the presence of bivalent cations such as calcium and magnesium $\left(\mathrm{Ca}^{2+} \mathrm{Mg}^{2+}\right)$ was found to improve transfection efficiency of bacteria and yeast (Xie et al. 1990; Neumann et al. 1996). The role of bivalent cations in gene electrotransfer is attributed to improved DNA adsorbtion to the cell membrane.

Electrofusion yield is also improved by the presence of bivalent cations in the medium (Ohno-Shosaku and Okada 1985; Vienken and Zimmermann 1985), while the presence of monovalent ions decreased the fusion yield (Rols and Teissié 1989). Nevertheless, cell electrofusion is a complex process and several biologically active substances affect its yield (Grobner, Velizarov, Berg 1996; Velizarov and Berg 1998a; Velizarov et al. 1998b; Liu et al. 2000).

\subsection{Osmotic Pressure}

Electroporation is further affected by electroporation buffer osmolarity. When it is carried out in a hypertonic media, cells are permeabilized at a lower voltage than cells maintained in isotonic media and exposed to the same electric pulse parameters. On the other hand increasing the osmotic pressure of the post-electroporation 
media (hypertonic media) facilitates the resealing of electroporated cells (Rols and Teissié 1990b).

Osmolarity of the electroporation media affects the cell size and shape changes caused by electroporation. The electroporation of cells in suspension results in an increase in cell diameter up to $30 \%$, which corresponds to $100 \%$ of volume increase, in isotonic medium, while the increase is significantly lower in hypertonic medium. In addition, the osmolarity of the medium plays an important role in post-pulse incubation (Golzio et al. 1998; Barrau et al. 2004).

As electrostatic and electrorepulsive forces play an important role in an initial step of gene electrotransfer process, when a highly charged DNA molecule adsorbs to cell membrane, the medium osmolarity is an important factor in this process. Hypotonic media facilitate the gene electrotransfer in mammalian cell because of the decrease in repulsion between DNA and cell membrane. The initial step of successful DNA-membrane interaction is a key step for successful gene transfer (Wolf et al. 1994; Golzio et al. 1998). On the other hand, a hypertonic medium improves gene electrotransfer of gram-positive bacteria because of improved cell survival. Higher electric pulse amplitudes can be used, which result in better electroporation of the cell membrane and DNA loading into the cell (Xue et al. 1999). Also in plant cells, a hypertonic medium is used for improved gene electrotransfer. Osmotic treatment of an intact plant cell causes plazmolysis, which is a consequence of water loss from the vacuole. The plant cells vacuoles maintain high turgor pressure, which enables cell membrane to attach closely to the cell wall. When a cell is placed in hypertonic solution, the membrane is pulled away from the cell wall because of water loss from the cytoplasm, and the cell shrinks. These partial detachments of the cell wall from the membrane cause a void space between the rigid cell wall and the cell membrane and enables the required contact between the cell membrane and the macromolecule that is being introduced into the cytoplasm (Fig. 5) (D’Halluin et al. 1992; Ganeva et al. 1995; Sabri et al. 1996a; Eynard et al. 1997; Wu and Feng 1999).

As in gene electrotransfer, the medium osmolarity also plays an important role in cell electrofusion. The electrofusion efficiency is increased in hypotonic medium due to increased osmotic pressure in the cell (Rols and Teissié 1990b, Barrau et al. 2004). When the distance between adjusted cells is reduced, repulsive forces between neighboring cells become significant; however, those forces are balanced by osmotic pressure. In a hypertonic electroporation medium, electrofusion yield is reduced (Abidor et al. 1994).

In brief, in this section the effects of electric pulse parameters, electroporation medium composition, and osmotic pressure are described. Among electric pulse parameters, pulse amplitude, duration, number, and repetition frequency significantly affect electroporation. When these parameters exceed their optimal values, cell viability is affected and irreversible electroporation takes place. For introduction of small and large molecules, different electric pulse parameters need to be used. Small molecules are efficiently introduced into the cell by application of short electric pulses in range of tens to hundreds of microseconds. The transport of small molecules takes place predominately after the pulse by diffusion. On the 


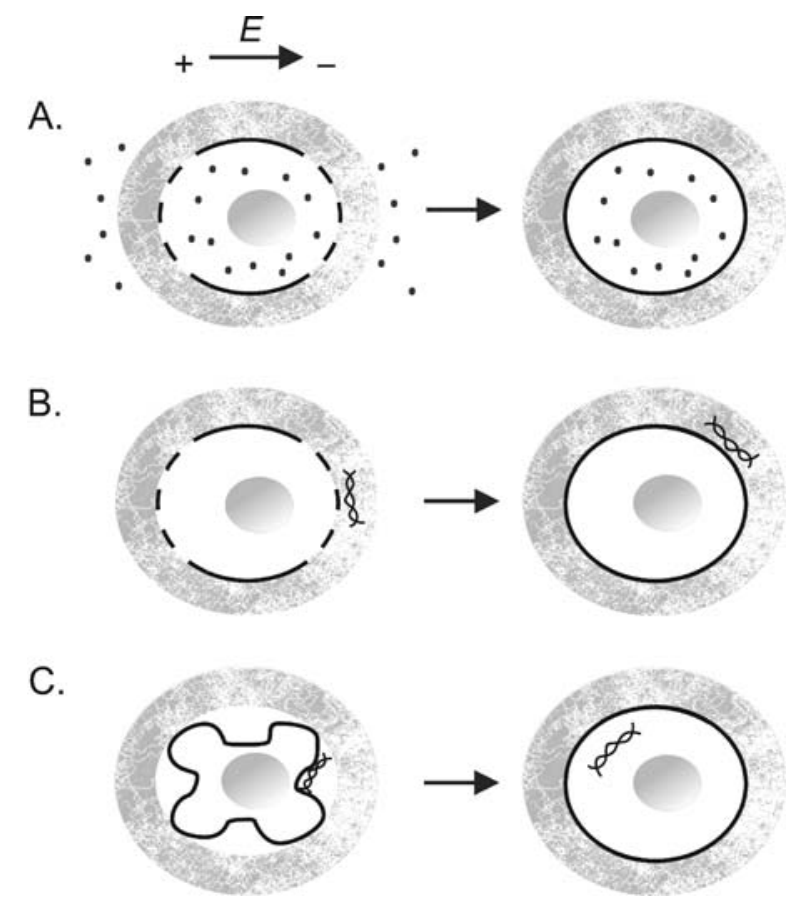

Fig. 5 Electroporation of a cell with cell wall. (A) Introduction of small molecules is not affected by cell wall. (B) DNA molecule is trapped in the cell wall. (C) Plasmolysis improves DNA transport into the cell

other hand, for macromolecules, long 5 to $10 \mu$ s pulses with relatively low pulse amplitude are used. Besides, for successful gene electrotransfer, DNA has to be present in the medium before electric pulses are applied, while small molecules can enter the cell even if added after the pulse. Electric pulse parameters for cell electrofusion are similar to those used for introduction of small molecules, but the critical voltage required is higher. For irreversible electroporation that is used for inactivation of microorganisms, the electric pulse parameters should exceed critical value, as cell death is the desired result of such application. In addition to the electric pulse parameters, electroporation medium composition and its osmolarity strongly affect electroporation as well as related gene electrotransfer and electrofusion.

\section{From Single-Cell to Tissue}

Single-cell electroporation is a suitable tool for the study of basic electroporation mechanisms. A few attempts were made to observe ultra-structural changes related to electroporation (Stenger and Hui 1986; Escande-Geraud et al. 1988); however, the process is too fast. Besides, chemical composition and fluid characteristics of the thin cell membrane make direct observation of primary membrane changes 
related to electroporation very difficult (Weaver and Chizmadzev 1996). The attempt was made to use rapid freezing scanning microscopy to determine the changes in membrane structure (Chang and Rees 1990); however, the size of the pores observed was $20 \mathrm{~nm}$ up to $120 \mathrm{~nm}$, too large compared to theoretically estimated $1 \mathrm{~nm}$ (Weaver and Chizmadzev 1996), and the observed pores were most probably secondary structures (Rols 2006).

At the cell membrane level, the induced transmembrane potential was imaged by fluorescence probes sensitive to transmembrane potential changes induced by an external electric field. Temporal and spatial induction of transmembrane potential on the cell membrane that responds to externally applied electric field was observed with potentiometric dyes (Gross et al. 1986; Kinosita et al. 1988; Tekle et al. 1990; Tekle et al. 1991; Hibino et al. 1991). The results obtained in those experiments on a single spherical cells are in good agreement with the theoretically calculated values obtained by Schwan's equation (Loew 1992). The value of induced transmembrane potential sustainable for living cell electroporation was determined to be 1 V (Zimmermann 1982; Tsong 1991). Later the value of the induced transmembrane potential that triggers electroporation was determined to be in the range of 200-500 mV (Marszalek et al. 1990; Grosse and Schwan 1992; Teissié et al. 1993). These values obtained by fluorescence imaging and calculations were further confirmed by direct measurement at the single-cell level using patch clamp technique (Ryttsen et al. 2000).

The value of induced transmembrane voltage depends on the cell size, shape, and the position of the cell with respect to the direction of applied electric field (Sale and Hamilton 1967; Zimmermann 1982; Graškova et al. 1996; Teissié et al. 1999; Kotnik and Miklavčič 2000; Valič et al. 2003; Valič et al. 2004). For a spheroidal cell, the maximum induced transmembrane potential strongly depends on its orientation with the respect to the electric field (Fig. 6). It is maximum when the spheroidal cell is parallel to the applied electric field (Valič et al. 2003).

The distribution of induced transmembrane potential is asymmetric due to native transmembrane potential that is present in live cells. As the induced transmembrane potential caused by externally applied electric pulses is superimposed to the resting membrane potential of the cell, the side of the cell facing the anode is hyperpolarized while the side facing the cathode is depolarized (Mehrle et al. 1985; Gabriel and Teissié 1997, 1999; Pucihar et al. 2006). The membrane labeling with fluorescent probes allows imaging of the membrane area affected by applied electric pulse (Gabriel and Teissié 1997). It was found that the membrane resting potential has a significant effect on asymmetric electroporation, especially when the induced transmembrane potential is close to the threshold voltage that triggers electroporation. This, however, is the case in majority of the applications in which cell viability needs to be preserved (Valič et al. 2004).

The cell shape affects the site of cell membrane electroporation, and it is especially important in attached cells, as they are not at regular shape. The calculation of induced transmembrane potential on single cells, therefore, depends on the realistic cell shape that needs to be taken into account as it affects the calculated distribution of the induced transmembrane potential (Pucihar et al. 2006). 
A.

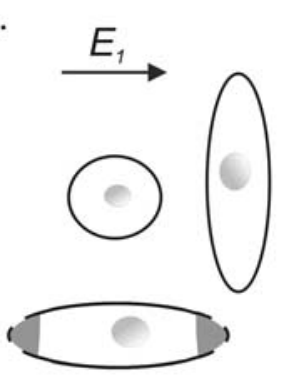

C.

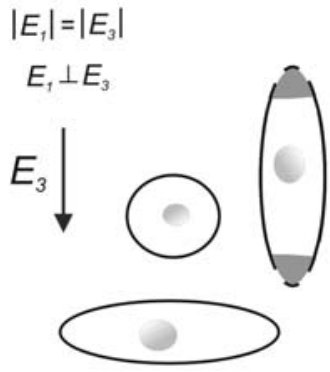

B.

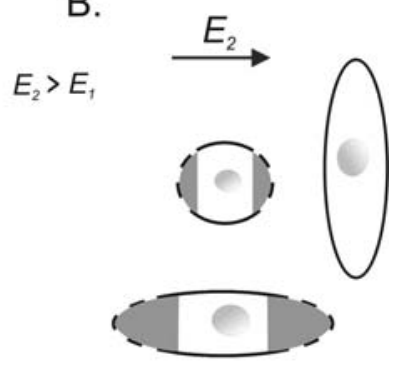

D.

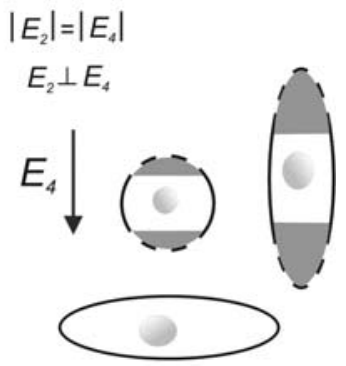

$E_{2}>E_{1}, E_{4}>E_{3}$

Fig. 6 Effect of electric field orientation on electroporation of different cell sizes and shapes. (A) Electric field parallel to elongated cell. (B) Electric pulse amplitude is increased. (C) Orientation of electric field is changed. (D) Electric pulse amplitude is increased

Although a single-cell model is a valuable tool for the study of basic mechanisms of electropotaion, it is not the best method to predict electroporation behavior in a tissue. As a tissue is composed of cells that are close to each other, dense cell suspensions represent an intermediate level between the single-cell level and the tissue (Abidor et al. 1994). Neighboring cells, even if they are not in direct contact, affect each other due to mutual electrical shading (Susil et al. 1998; Pavlin et al. 2002; Pucihar et al. 2006). For electroporation of cell suspensions, the proportion of the cells in the total volume is important. When they represent less than $1 \%$ of the volume fraction they behave as single cell, while for volume fraction greater than $10 \%$ or for clusters of cells, the induced transmembrane potential is affected by the suspension density (Susil et al. 1998, Pavlin et al. 2002; Pavlin et al. 2007). The fraction of electroporated cells decreases with increase in cell density and the resealing of cells in dense cell suspensions is slower. In dense cell suspensions, cell clusters, and multicellular spheroids it was found that the molecular transport is slower due to slower diffusion of molecules into the interior of such cluster or spheroid (Abidor et al. 1994; Canatella et al. 2004; Pucihar et al. 2007).

Dense cell suspensions can serve as a model for tissues with homogeneous structure composed of similar cells in close contact; nevertheless, most tissues are 
not homogeneous. Tissues are composed of different cell types that are irregularly shaped, are vascularized, and present different electrical properties. All the mentioned factors affect the distribution of electric field within the tissue and consequently its electroporation efficiency (Miklavčič et al. 1998; Šemrov and Miklavčič 1998; Pucihar et al. 2006). Furthermore, cells in tissue are connected by gap junctions for intracellular communications and transport, which change the electroporation behavior of such cells, and they behave as a single larger cell (Fear and Stuchly 1998a, 1998b). For efficient tissue electroporation in vivo, the electric field distribution, which depends on electrode geometry, position, and electrical properties of the sample, is crucial (Šemrov and Miklavčič 2000). The electrical properties of biological tissue such as conductivity and permitivity change once the tissue is permeabilized and the electric field distribution is changed. The largest part of these changes is attributed to increased membrane conductivity due to electroporation (Pavšelj et al. 2005b; Šel et al. 2005). Changes in membrane conductivity need to be taken into account when performing electroporation with multiple needle electrodes and can be used for detection of cell membrane electroporation and for pulse delivery control. Recently these changes were used for regulating the output voltage for in vivo gene transfection (Cukjati et al. 2007). One of the major problems with respect to conductivity measurements in vivo is the inhomogeneous distribution of current density and electric field due to inhomogeneous and anisotropic properties of the tissue. For successful tissue electroporation, anatomically based mathematical models are important tools for prediction of the outcome of the treatment (Miklavčič et al. 1998; Šemrov and Miklavčič 1998; Brandinsky and Daskalov 1999; Miklavčič et al. 2000; Šel et al. 2007; Miklavčič et al. 2006a).

In brief, in this section the differences between single-cell and tissue electroporation are described. Single-cell electroporation is a suitable tool for study of basic electroporation mechanisms. The situation is more complex in tissues as they are composed of cells that are in close contact with each other and their proximity affect electroporation. Besides, most tissues are not homogenous structures, they are composed of different cell types that are irregularly shaped, are vascularized, and have different electrical properties that affect current density and electric field distribution, all of these affecting electroporation effectiveness. Mathematical models are thus a valuable tool for predicting electroporation behavior of the tissue.

\section{Electrodes/Shaping the Electric Field}

Electroporation is used for different purposes and depending on the application one should chose the right electrodes to obtain the desired result.

For different applications, different types of electrodes are available and can be classified according to their geometry into different groups: plate, needle, wire, and tweezers electrodes (Miklavčič and Puc 2006b). In certain cases, special electrodes are needed; for example, for individual-cell electroporation, specially designed microelectrodes are required (Lundqvist et al. 1998; Ryttsen et al. 2000; Olofsson et al. 2003). For treatment of large volumes of sample and for flow electroporation, 
electroporation chambers that allow efficient treatment were designed and successfully tested. They were successfully used for gene transfection or water treatment (Stopper et al. 1987; Teissié and Conte 1988a; Teissié and Rols 1988b; Rols et al. 1992b; Li et al. 2002; Teissié et al. 2002). The choice of most suitable electrodes for a given application depends also on the characteristics of the treated sample (Miklavčič et al. 2006b).

For reversible electroporation used in medicine, electrode design have to allow efficient electroporation and at the same time cause as little cell damage of the surrounding tissue as possible. In in vivo electroporation, electrical properties of the treated tissue have to be taken into account, as they vary significantly among different tissues. In electroporation, mathematical models taking into account the tissue conductivity changes can be very useful for proper electrode selection and their positioning with respect to the tissue that needs to be electroporated (Pavšelj et al. 2005b; Šel et al. 2005, 2007), since the electric field distribution can be efficiently modified by electrode geometry and their position during the pulse application (Šel et al. 2005, 2007).

Irreversible electroporation, used in water sterilization and food preservation, where large volumes need to be treated and high electric fields need to be applied, requires different methodologies (Teissié et al. 2002). For flow electroporation, it is crucial that the pulse delivery frequency is linked to the flow rate in such a way that each cell that passes electroporation chamber receives electric pulse treatment. Liquid flow during electroporation affects causes cell elongation therefore electric field orientation with respect to cell is important (Fig. 6) (Teissié et al. 2002).

In brief, in this section, electrode type and effects of electrode shape and positioning on electroporation effectiveness are described. The choice of proper electrode shape and their position during the pulse application is crucial for successful treatment, as they affect the electric field distribution. The most appropriate electrode type and positioning depends on the application.

\section{Different Applications}

Various applications of electroporation have already been proposed, ranging from gene electrotransfer in biotechnology, biology, and medicine to cell killing in water sterilization, food preservation, and tissue ablation (Fig. 7) (Miklavčič et al. 2006b). These electroporation-based technologies and treatments require proper selection and choice of pulse parameters, electrodes, and pulse generators (Puc et al. 2004). In this section different applications in biology, biotechnology, and medicine are briefly reviewed.

\subsection{Use in Medicine}

In medicine, electroporation is used with the method called electrochemotherapy in clinical practice for improved drug delivery for cancer treatment, and in preclinical 


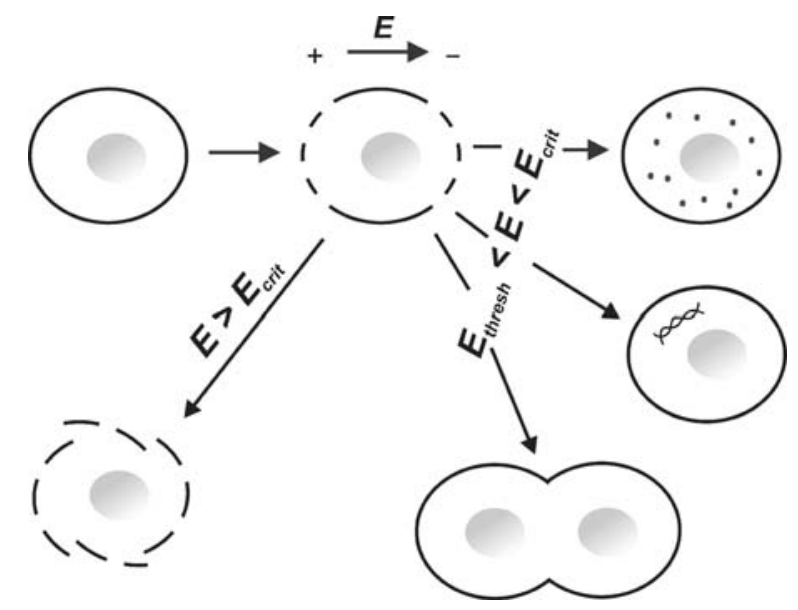

Fig. 7 Different application of electroporation. When external electric field reaches threshold value $\left(\mathrm{E}_{\text {thresh }}\right)$ cell membrane is electroporated. Small and large molecules can be introduced into the cell or when two cells are in close contact their membranes can fuse. When external electric field exceeds certain critical value $\left(\mathrm{E}_{\text {crit }}\right)$ irreversible electroporation occurs resulting in cell membrane disintegration and cell death

trails for gene electrotransfer (Serša et al. 1995; Serša et al. 1998; Serša et al. 2003; Heller et al. 1999; Mir and Orlowski 1999; Mir 2000). From the point of view of medical applications, it is more convenient to use a high-repetition pulse frequency rather than $1 \mathrm{~Hz}$ pulse repetition, which is currently used in clinical trials. This is important when larger tumor nodules need to be treated and when multiple needle electrodes are used. In that case, a large number of pulses need to be delivered to each of the pairs of the electrodes, which would represent an unpleasant and a relatively long treatment time, if pulses were delivered at $1 \mathrm{~Hz}$ repetition frequency. The application of pulses with higher repetition frequency does not significantly affect the electrochemotherapy efficiency and the treatment is less unpleasant than application of pulses with standard $1 \mathrm{~Hz}$ repetition frequency (Miklavčič et al. 2005; Županič et al. 2007).

At the in vivo level, tissue vascular lock is observed due to disruption of blood vessel network after the application of high-voltage pulses. Consequently, the tissue oxygenation level is reduced by electroporation resulting in enhanced tumor cell death (Serša et al. 1999; Čemaar et al. 2001; Serša et al. 2002; Gehl et al. 2002; Kanthou et al. 2006).

\subsection{Water Sterilization and Food Preservation}

Irreversible electroporation is used in food technology for liquid food sterilization, food preservation, and water treatment as a tool for efficient cell killing (Graškova et al. 1996; Danfelter et al. 1998; Lebovka and Vorobiev 2004), which 
is important for nonthermal food preservation and for freshwater treatment (Gould 1995; Lebovka et al. 2002; Lebovka and Vorobiev 2004; Teissié et al. 2002).

The benefit of nonthermal food preservation is the maintenance of food quality (Zhang et al. 1995; Ade-Omowaye et al. 2001). The design of static and flow chambers for liquid food pasteurization by electroporation has to take into account sufficient electric field strength and treatment times (Zhang et al. 1995). For efficient use of irreversible electroporation in food industry, identification of optimal parameters is crucial (Angersbach et al. 2000, Lebovka et al. 2000, 2002). In some cases, irreversible electroporation is combined with other treatments for superior results. For example, inactivation of Escherichia coli was obtained by combination of electroporation and high-temperature treatment. For efficient liquid food sterilization, a apparatus was developed, which combines thermal, high pressure, and electric pulse treatment. The main advantage of the system is that it is not only effective for inactivation of vegetative cells but it efficiently eradicates even spores (Uemura and Isobe 2002). As yet, irreversible electroporation treatment alone is effective for inactivation of vegetative microorganisms; its effectiveness is not sufficient for the inactivation of their spores (Gould 1995).

Similarly, as for food preservation, the combination of irreversible electroporation and other established methods is used for freshwater treatment. Such a combination was applied for electroporation-assisted water chlorination, which was efficient for elimination of Giardia muris (Haas and Atrualiye 1999). Further, synergistic effect of electroporation and photodynamic treatment was reported. Such combined treatment reduced the time needed for efficient cell elimination as compared with photodynamic treatment alone (Wang et al. 1998; Zhou et al. 2000).

\subsection{Electroporation of Bacteria and Yeast}

Gene electrotransfer of bacteria provides an important methodology for the improvement of microorganisms used in food and pharmaceutical industry. Electroporation is used as an efficient transformation technique for gram-positive and gram-negative bacteria (Chassy et al. 1988; Dower et al. 1988; Fiedler and Wirth 1988; Tryfona and Bustard 2005). Mechanisms of gene electrotransfer were studied extensively, among which surface binding and diffusion through electropores, effective electric pulse parameters, and the effect of DNA topology on transformation efficiency were investigated (Xie et al. 1990; Xie and Tsong 1992; Xie et al. 1992).

The optimal temperature for bacterial gene electrotransfer depends on the strain used. For slow-growing mycobacteria, elevated temperatures markedly increases electrotransformation efficiency. On the contrary, for fast-growing strains the highest transformation is achieved at low temperatures (Wards and Collins 1996). Furthermore, different bacterial culture conditions were reported for optimal electrotransformation of Corynobacterium. In some species of Corynobacterium, cultivation at suboptimal temperature conditions and heat shock following electric pulse application significantly increased gene electrotransfer. The heat shock effect contributed to the inactivation of the restriction system present in bacteria, as it was observed only 
with xenogenic DNA, where the restriction system inhibits DNA expression (Van der Rest et al. 1999). Optimization of technical conditions for gene electrotransfer in bacteria is crucial for successful use in industry (Kim et al. 2005; Mason et al. 2005). Among the most important factors for improved gene electrotransfer of bacteria is the disruption of the cell wall, which presents an obstacle for macromolecular uptake by the cell. Optimization of electric pulse parameters and the choice of the compatibility of foreign and endogenous plasmids is also required (Kim et al. 2005). Optimization of conditions for gene electrotransfer is not only species and strain specific, it also depends on the environmental conditions, from which bacteria was isolated (Mason et al. 2005).

The complexity of cell wall and cell shape of given bacterial strain determines the optimal parameters for efficient gene electrotransfer to bacteria. The optimal field strength is usually lower for gram-positive bacteria, rod-like bacilli, and cocci, and higher for gram-negative bacteria (Dower et al. 1992). Rod-like cells orient with the long axis in the direction of the electric field (Neumann 1992). Electroporation of rod-like bacteria was thus described as a multistep process in which orientation of the rod in the electric field plays an important role. When the rod is parallel to the electric field, the effective electroporation takes place at lower pulse amplitudes as compared to non-oriented one. The pulse duration must thus be sufficient for effective orientation and successful electroporation (Eynard et al. 1997; Eynard et al. 1998).

Similar to bacteria, the yeast species have a cell wall that interferes with the transport of molecules to the cell. Macromolecules are trapped in the yeast cell wall (Ganeva et al. 1995). At the same time the cell wall also presents a barrier for macromolecule release from the cell. Different yeasts species belonging to Saccharocmyce taceae family are used in biotechnology as a cell factory due to their ability to produce desired proteins (Meilhoc et al. 1990). When electroporation is used for macromolecular release, besides cell membrane alteration produced by electric pulses, the cell wall alterations were proposed as mechanism responsible for macromolecule release from the cell interior (Ganeva et al. 2003, 2004; Suga et al. 2007). This statement, however, is not in agreement with other authors who assume that the cell wall, at least in plant species, is not altered by electric pulse application (Joersbo and Brunstedt 1991).

\subsection{Plant Protoplast Electroporation}

Electroporation can be used as an efficient method for transfer of foreign genes into plant protoplasts of monocotyledons and dicotyledons (Fromm et al. 1985). In case of gene electrotransfer, the range of plants is not limited by pathogen host specificity as in the case of gene transfer by Agrobacterium tumefaciens. Besides, large amounts of protoplasts can be transformed at the same time (Saunders et al. 1989).

Gene electrotransfer of plant protoplasts was successfully applied for transformation of several crop species such as maize, rice, wheat, sorghum, soybean, and rye (Fromm et al. 1986; Lee et al. 1986; Christou et al. 1987; Pitt et al. 1997; 
Quecini et al. 2002). Cell viability preservation is crucial for production of transgenic plants, as transformed protoplast should maintain the ability of normal organogenesis. Conflicting reports about electrotransfected plant protoplast regeneration ability are found in the literature. Some authors reported increased cell division, plant regeneration, and DNA synthesis in protoplast transformed by electroporation (Rech et al. 1987; Rech et al. 1988; Chand et al. 1988; Ochatt et al. 1988; Joersbo et al. 1991), while others found slower plant regeneration of electrotransfected protoplasts (Quecini et al. 2002). In some studies, increasing electric filed strength and the number of pulses decreased plant protoplast viability and plating efficiency. Nevertheless, the regeneration of plantlets was stimulated (Mordhorst and Lorz 1992).

Electroporation can be successfully used for production and extraction of plant metabolites from cell culture. Plany cell suspension cultures can be used for largescale production of many plant secondary metabolites, such as different alkaloids (Kutney 1982; Yang and Bayraktar 2003, Ladygin 2004; Vanisree et al. 2004). One of the advantages of such production of secondary metabolites is that they are extractable form the cell culture. When plant cell culture is combined with efficient cell transfection methods, it can provide constant levels of desired metabolite production and therefore an important source for plany secondary metabolites (Vanisree et al. 2004). Electroporation is a suitable technique for such applications as it is applicable to different species and suitable for continuous production of desired product. It is important to note that cell viability and cell biosynthetic capabilities are not affected by the treatment when electroporation parameters are chosen properly (Yang et al. 2003).

Another important application of electroporation in plant protoplast is electrofusion that allows production of hybrid plant cells. As an effective field strength for cell fusion depends on the cell diameter, the amplitude needed for protoplast fusion is much lower than for animal or bacterial cells, as protoplast diameter is much larger than that of animal or bacterial cells. However, the method presents its limitations as hybrid cells obtained from electrofusion are mainly genetically instable and present multiple ploidity levels (Saunders et al. 1989).

\subsection{Transfection of Intact Plant Tissue}

The limitations related to electrotransfected protoplast regeneration are overcome by gene electrotransfer in the intact plant cells. Even though the cell wall represents a barrier, osmotic shock pretreatment that provokes plasmolysis can be used to create a passage of molecules through the cell wall (D'Halluin et al. 1992; Ganeva et al. 1995; Sabri et al. 1996a; Eynard et al. 1997; Wu and Feng 1999).

Reactive oxidative species are produced in response to oxidative stress in mammalian and plant cells exposed to electric pulses (Biedinger et al. 1990; Gabriel and Teissié 1995a, Maccarrone et al. 1995; Sabri et al. 1996b, 1998). Even if the cell viability is not directly correlated with reactive oxidative species production, gene 
electrotransfer efficiency is improved by post-pulse treatment with antioxidants, which protect the cell from reactive oxidative species (Sabri et al. 1996; Sabri et al. 1998).

Electroporation is an alternative method for plant transformation. It is, however, still not widely used due to its low efficiency. Although it was effective in some species, such as maize (D'Halluin et al. 1992), a much lower efficiency was obtained in other species, such as wheat (Walden and Wingender 1995; RakoczyTrojanowska 2002). In some cases, gene electrotransfer in wheat was successful and electrotransfected explants were able to regenerate plants via somatic embryogenesis; however, the transformation was transient (He and Lazzeri 1998). The production of fertile transgenic wheat plants via tissue electroporation still depends on the quality of plant material used (Sorokin et al. 2000). The stable electrotransformation procedure as an alternative method for Triticae family crop species (wheat) transformation is still in development. Fully fertile plants that expressed transgenes and transmitted them to progenity were obtained from tritordeum, fertile amphiploid derived from durum wheat and wild barley, by tissue electroporation (He et al. 2001). Barley transfected by tissue electroporation resulted in stable genetic transformation (Gurel and Gozukirmizi 2000).

In brief, in this section different applications of electroporation were described. The method is successfully used in medicine in clinical practice as electrochemotherapy. Preclinical trials for gene electrotransfer are progressing and irreversible electroporation has a potential as a new surgical method for tissue ablation. Besides, irreversible electroporation is used for water sterilization and food preservation. In biotechnology gene electrotransfer is successfully used for improvement of microorganisms used in food and pharmaceutical industry. Gene electrotransfer is also used as efficient tool for manipulation of yeast cells and their ability to produce desired proteins. On the other hand, plant protoplast gene electrotransfer and electrofusion is used to obtain transgenic plants while plant cell cultures serve as bioreactors to produce desired secondary metabolites of economical interest. For production of transgenic plants, limitations associated to electroporated/fused protoplast regeneration are overcome by gene electrotransfer into intact plant tissue. The method has already been used successfully for some economically important species while for others the transfection efficiency and transformation stability is still not sufficient for wider use and needs further improvements.

\section{Understanding Electroporation of Different Cell Types}

Electroporation can be successfully used for different cell types although they differ in their electroporation behavior. While part of the differences can be attributed to the differences in cell size and shape, already mentioned before, some differences are related to biological characteristics of the treated cell (O'Hare et al. 1989; Rols and Teissié 1992a; Rouan et al. 1991; Čemaar et al. 1998; Čegovnik and Novaković 2004; Kandušer et al. 2006). Among such biological factors that affect 
cell membrane electroporation are membrane fluidity, cell cytoskeleton, and cell wall in bacteria, yeast, and plant cells.

\subsection{Influence of Cell Membrane Fluidity}

Cell membrane fluidity is a physical characteristic of biological membrane that changes with membrane composition and temperature. The content of cholesterol and the ratio between saturated and unsaturated fatty acids that are part of the membrane lipids determine cell membrane fluidity. It can be altered by chemical compounds that integrate into the membrane bilayer or by rapid temperature changes. On the other hand, slow environmental temperature changes cause changes in membrane composition in bacteria, yeast, and plant cells, as these organisms regulate their membrane fluidity in response to environmental factors.

It was reported that membrane fluidity affects the electroporation response of a cell exposed to electric pulses. Two conflicting findings on membrane fluidity effect on electroporation were reported. On the one hand, at physiological temperature less fluid membranes are permeabilized at lower voltages than the more fluid ones (Rols et al. 1990c; Kandušer et al. 2006). On the other hand, the effect of cell membrane fluidity on electroporation is just the opposite when membrane fluidity is altered by chilling. Different responses are found in different cell types. Low temperature had almost no effect on erythrocyte electroporation (Kinosita and Tsong 1979). In alga Valonia, rye leaf protoplast, porcine stratum corneum, and in our recent study on mammalian cell lines, exposure of cells to low temperature has as a consequent increase in a voltage required for successful electroporation (Coster and Zimmermann 1975; Pitt et al. 1997; Gallo et al. 2002; Kandušer, Šentjurc, Miklavčič, 2008). These temperature effects on electroporation were attributed to the lipid fluidity change produced by lower temperature (Gallo et al. 2002). Probably more than overall lipid fluidity changes, the membrane domain structure is responsible for the observed differences in electroporation behavior. Besides, the temperature probably affects electroporation by other means not only by cell membrane fluidity alterations.

Membrane fluidity is probably also involved in cell membrane electrofusion. It was reported that the membrane fluidity could be an important factor affecting molecular rearrangements in the electroporated cell membrane responsible for the cell fusion (Dimitrov and Sowers 1990). Moreover, in biological membrane fusion, the process depends on properties of the membrane lipid bilayer. It was shown that biological fusion is altered by changes in membrane lipid composition (Chernomordik et al. 1995). In addition, in electrofusion the presence of anesthetic agents or polylysine, substances that affect cell membrane fluidity, also affect cell fusion (Grobner et al. 1996; Velizarov et al. 1998b). It was also reported that in bacteria different temperature and culture conditions that affect membrane lipid composition and fluidity affect efficiency of gene electrotransfer (Wards and Collins 1996; Van der Rest et al. 1999). The effect of membrane fluidity on efficiency of gene electrotransfer was also observed in plant cells (Wu and Feng 1999). 


\subsection{Influence of Cell Cytoskeleton}

The cell cytoskeleton is a very dynamic structure, which is composed of actin filaments, microtubules, and intermediate filaments. It is responsible for cell shape maintenance and mobility (Janmey 1995). As the cell cytoskeleton interacts with cell membranes, it is expected that it also affects cell membrane electroporation.

Tubulin, which is a main component of microtubules, was found to play an important role in electroporation and electrofusion (Blangero et al. 1989; Rols and Teissié 1992a; Teissié et al. 1994; Kanthou et al. 2006). The experiments in which cell cytoskeleton was disrupted by chemical agents showed that the first two phases of electroporation, pore formation and expansion, are not affected by cytoskeleton integrity. On the contrary, the third phase of the electroporation process, cell membrane resealing is dramatically affected. In cells with disrupted cytoskeleton, cell membrane resealing is significantly faster than in intact cells. Similar results were obtained when erythrocytes cytoskeleton was disrupted by heat treatment or when cells in the phase of mitosis, when tubulin cytoskeleton is rearranged in mitotic spindle were electroporated (Rols and Teissié. 1992a; Teissié et al. 1994).

The effect of electroporation on cell cytoskeleton was studied in different cell types, and its disorganization was observed during cell electrofusion (Blangero et al. 1989; Wu and Feng 1999; Rols and Teissié 1992a; Harkin and Hay 1996; Teissié et al. 1998; Kanthou et al. 2006). In some cases, tubulin and vimentin intermediate filaments disruption was dependent on the composition of electroporation media. In media with similar ionic composition as cytoplasm, the cell cytoskeleton disruption was prevented (Harkin and Hay 1996). Disruption of cell cytoskeleton is observed immediately after electroporation and recovery took place in 1 hour after the pulse application. Although electroporation interferes with the organization cytoskeleton filaments, it does not result in degradation of cytoskeletal proteins (Kanthou et al. 2006).

\subsection{Influence of Cell Wall in Bacteria, Yeast, and Plants}

The cell wall chemical composition varies from bacteria, to yeast, to plant cells. The bacterial cell wall is composed of cross-lined peptidoglycans and polysaccharides; nevertheless, its composition varies in different types of bacteria. Cell walls of bacteria present additional surface structures such as capsules, slimes, S layers, and sheals (Beveridge and Graham 1991; Schaffer and Messner 2005). In yeast species, the chemical composition of cell walls varies with species and is composed, in case of Saccharomyces cerevisiae, of glucan, manoprotein, and chitin. The main component is glucan that forms a microfibrilar matrix to which other components are bound (Mazan et al. 2006). In plant species the primary cell wall is composed of cross-linked pectines and hemicellulose molecules. The free spaces among molecules that constitute the cell wall are species and tissue specific, ranging from 3.5 to $5.2 \mathrm{~nm}$ (Carpita et al. 1979). The cell wall structure is permeable to 
small molecules but represents a barrier to large molecules such as DNA or proteins (Wu and Feng 1999).

Regardless of the cell wall chemical composition, it presents a barrier to electrofusion and is a limiting factor for gene electrotransfer. Nevertheless, the cell wall does not affect transport of small molecules. The cell wall does not interfere with electric pulses, which cause electroporation of cell membrane, as only slight differences were obtained when the electroporation of plant protoplast and intact plant cells was compared (Saunders et al. 1995). Small molecules can freely diffuse through the cell wall; therefore, their loading into cytoplasm was not affected significantly by the presence of the cell wall in bacteria, yeasts, or plants. From those results, it was concluded that electroporation of cell membrane on itself is not affected by the presence of the cell wall (Ganeva et al. 1995; Aouida et al. 2003; Sauders et al. 1995).

On the other hand, when large molecules need to be introduced into the cell, such as DNA, for gene electrotransfer of bacteria, transfection efficiency is improved when the cell wall is partially disrupted by chemical agents (Ganeva et al. 1995). It was also reported that electrotransformation of the gram-positive bacteria is less effective than in gram-negative bacteria due to the thicker and denser cell walls in gram-positive species (Dower et al. 1992; Trevors et al. 1992, Kim et al. 2005). A similar situation occurs in yeast species, where a cell wall represents a barrier for introduction of macromolecules into the cell. Observation of fluorescent $70 \mathrm{kDa}$ dextranes during electroporation of yeast revealed that those macromolecules are trapped in the wall. The presence of macromolecules at the cell membrane level was thus reduced and consequently their loading into the cytoplasm was smaller than it would be in a cell without a cell wall (Ganeva et al. 1995). To improve the transport of macromolecules through the cell wall of bacteria, yeast, and plant cells, different pretreatments were suggested. Before electroporation, partial disruption of the cell wall was effective for bacteria and yeast, while for plant cells, pre-pulse plasmolysis was successfully applied (D’Halluin et al. 1992; Ganeva et al. 1995; Sabri et al. 1996a; Eynard et al. 1997; Wu and Feng 1999).

In brief, in this section characteristics of different cell types on electroporation effectiveness are described. Biological characteristics of treated cells such as membrane fluidity, integrity of cytoskeleton, and presence of cell wall in bacteria, yeast, and plant cells affect electroporation. These characteristics need to be taken into account when optimizing electroporation parameters. Besides, for improved loading of macromolecules into the cells with the cell wall, pretreatments that partly disrupt cell wall or cause plasmolysis can be successfully used.

\section{Conclusions}

Electroporation is a useful technique in biotechnology and medicine for introduction of different molecules, electrofusion, or water sterilization and food preservation. Among the different theoretical models that describe electroporation, the transient aqueous pore model is the most widely accepted. This model predicts hydrophilic 
pore formation that takes place in a cell membrane as a response to an induced electric field. Electroporation can be reversible or irreversible, depending on the electric pulse parameters used. The effectiveness of electroporation is determined by electric pulse parameters, electroporation medium composition, and its osmotic pressure. Among the electric pulse parameters, pulse amplitude, duration, number, and repetition frequency are most important. Pulse amplitude is a critical parameter as, when it reaches threshold value, it triggers the electroporation process. When electric pulse parameters exceed their optimal values, cell viability is affected and irreversible electroporation takes place. For introduction of small and large molecules, different electric pulse parameters need to be used. Small molecules are efficiently introduced into the cell by application of short electric pulses in range of tens to hundreds of microseconds. The transport of small molecules takes place predominately after the pulse by diffusion. On the other hand, for macromolecules, long 5 to $10 \mu$ s pulses with relatively low pulse amplitudes are used. In addition, for successful gene electrotransfer, DNA has to be present in the medium before electric pulses are applied, while small molecules can enter the cell even if added after the pulse is applied. Electric pulse parameters for cell electrofusion are similar to those used for introduction of small molecules, but the threshold voltage required is higher. For irreversible electroporation that is used for inactivation of microorganisms, the electric pulse parameters should exceed critical value as cell death is the desired result of such applications. Electroporation medium composition and its osmolarity affect electroporation and related gene electrotransfer and electrofusion.

The basic mechanisms of electroporation were mainly studied at the single-cell level, although the situation is more complex in a tissue. The tissue is composed of cells that are in close contact with each other and their proximity affects electroporation. In addition, most tissues are not homogenous structures. They are composed of different cell types that are irregularly shaped and have different electrical properties that affect current density and electric field distribution and consequently also electroporation effectiveness. The mathematical models are thus a valuable tool for prediction of electroporation behavior of the tissue. In addition, the electrode type, shape, and positioning affect electroporation effectiveness. The choice of proper electrode type, shape, and positioning is crucial for successful treatment, as it affects the electric field distribution and depends on the application.

Electroporation has many different applications; the method is successfully used in medicine in clinical practice as electrochemotherapy. Preclinical trials for gene electrotransfer are in progress, and recently irreversible electroporation was suggested as a new surgical method for tissue ablation. In addition, irreversible electroporation is used for water sterilization and food preservation. In biotechnology, gene electrotransfer is successfully used for improvement of microorganisms used in food and pharmaceutical industry and for plant cell cultures that produce secondary metabolites. On the other hand, gene electrotransfer in plant protoplast or protoplast electrofusion is used to obtain transgenic plants. Limitations found in protoplast regeneration are overcome by gene electrotransfer into intact plant tissue. The method is successfully used for some important crop species, while for others the 
transfection efficiency and transformation stability is still not sufficient for wider use and needs further improvements.

Although electroporation is used in a wide range of different cell types, biological characteristics of the treated cell, such as membrane fluidity, integrity of cytoskeleton, and presence of cell wall in bacteria, yeast, and plant cells, affect its efficiency. Specific characteristics of different cells need to be taken into account when optimizing electroporation parameters. The cell wall that presents a barrier to large molecules loading into the cell can be partly disrupt or cell can be plasmolysed. Such pretreatment improves electroporation effectiveness.

It can be concluded that electroporation can be efficiently used for different applications in biotechnology and medicine if proper conditions are chosen and characteristics of the treated sample are taken into account.

Acknowledgments The authors wish to thank mag. Selma Čorović for preparation of the figures, Dr. Alenka Maček-Lebar and Anže Županič for their useful comments. The work was financially supported by Slovenian Research Agency (ARRS).

\section{References}

Abidor, I.G., Arakelyan, V.B., Chernomordik, L.V., Chizmadzev, Y.A., Pastusenko, V.F. and Tarasevich, M.R. (1979) Electric breakdown of lipid membranes. I. The main experimental facts and their quantitative discussion. Bioelectrochemistry and Bioenergetics 6, 37-52.

Abidor, I.G., Li, L.H. and Hui, S.W. (1994) Studies of cell pellets: II Osmotic properties, electroporation, and related phenomena: membrane interaction. Biophysical Journal 67, 427-435.

Ade-Omowaye, B.I.O., Angersbach, A., Taiwo, K.A. and Knorr, D. (2001) Use of pulsed electric field pretreatment to improve dehydration characteristics of plant based foods. Trends in food Science and Technology 12, 285-295.

Aouida, M., Tounekti, O., Belhadj, O. and Mir, L.M. (2003) Comparative roles of the cell wall and cell membrane in limiting uptake of xenobiotic molecules by Saccharomyces crevisiae. Antimicrobial Agents and Chemotherapy 47, 2012-2014.

Angersbach, A., Heinz, V. and Knorr, D. (2000) Effects of pulsed electric fields on cell membranes in real food systems. Innovative Food Sciences and Emerging Technologies 1, 135-149.

Andre, F. and Mir, L.M. (2004) DNA electro transfer: its principles and an updated review of its therapeutic applications. Gene Therapy 11, S33-S42.

Andreson, G.L. and Evans, G.A. (1989) Optimization of electroporation for transfection of mammalian cell lines. Analytical Biochemistry 180, 269-275.

Barrau, C., Teissié, J. and Gabriel, B. (2004) Osmotically induced membrane fusion facilitates the triggering of living cell electroporation. Bioelectrochemistry 63, 327-332.

Beveridge, T.J. and Graham L.L. (1991) Surface layers of Bacteria. Microbiological Reviews 55, 684-705.

Beveridge, J.R., MacGregor S.J., Marsili, L., Anderson J.G., Rowan, N.J. and Farish, O. (2002) Comparison of the effectiveness of biphase and monophase rectangular pulses for the inactivation of micro-organisms using pulsed electric fields. IEEE Transactions on plasma Science $30,1525-1531$.

Biedinger, U., Youngman, R.J. and Schnabl, H. (1990) Differential effects of electrofusion and electropermeabilization parameters on the membrane integrity of plant protoplasts. Planta 180, 598-602. 
Bilska, A., DeBruin, K.A. and Krassowska, W. (2000) Theoretical modeling of the effects of shock duration, frequency and strength on the degree of electroporation. Bioelectrochemistry 51, $133-143$.

Blangero, C., Rols, M.P. and Teissié, J. (1989) Cytoskeletal reorganization during electric field induced fusion of Chinese hamster ovary cells grown in monolayers. Biochimica et Biophysica Acta 981, 295-302.

Brandinsky, K. and Daskalov, I. (1999) Electrical field and current distributions in electrochemotherapy. Bioelectrochemistry and Bioenergetics 48, 201-208.

Bureau, M.F., Ghel, J., Deleuze, V., Mir, L.M. and Scherman, D. (2000) Importance of association between permeabilization and electrophoretic forces for intramuscular DNA electro transfer. Biochimica et Biophysicqa Acta 1474, 353-359.

Canatella, P.J., Karr, J.F., Petros, J.A. and Prausnitz, M. (2001) Quantitative study of electroporation-mediated molecular uptake and cell viability. Biophysical Journal 80, $755-764$.

Canatella, P.J., Black, M.M., Bonnichsen, D.M., McKenna, C. and Prausnitz, M.R. (2004) Tissue electroporation: quantification and analysis of heterogeneous transport in multicellular environments. Biophysical Journal 86, 3260-3268.

Carpita, N., Sabularse, D., Montezinos, D. and Delmer, D.P. (1979) Determination of the pore size of cell walls of living plant cells. Science 205, 1144-1147.

Chang, D.C. and Reese, T.S. (1990) Changes in membrane structure induced by electroporation as revealed by rapid-freezing electron microscopy. Biophysical Journal 58, 1-12.

Chang, D.C., Chassy, B.M., Saunders, J.A. and Sowers, A.E. (1992) Guide to electroporation and electrofusion, Academic Press, San Diego.

Chand, P.K., Ochatt, S.J., Rech, E.L, Power, J.B. and Davey M.R. (1988) Electroporation stimulates plant regeneration from protoplasts of the woody medical species Solanum dulcamara L. Journal of Experimental Botany 39, 1267-1274.

Chassy, B.M., Mercenier, A. and Flickinger J. (1988) Transformation of bacteria by electroporation. Trends in Biotechnology 6, 303-309.

Chernomordik, L., Kozlov, M.M. and Zimmerberg (1995). Lipids in biological membrane fusion. The Journal of Membrane Biology 146, 1-14.

Christou, P., Murphy, J.E. and Swain, W.F. (1987). Stable transformation of soyabean by electroporation and root formation from transformed callus. Proceedings of the National Academy of Sciences USA 84, 3962-3966.

Coster, H.G.L. and Zimmermann, U. (1975) The mechanism of electrical breakdown in the membranes of Valonia utricularis. Journal of Membrane Biology 22, 73-90.

Cukjati D., Batiuskaite D., André F., Miklavčič D. and Mir L.M. (2007) Real time electroporation control for accurate and safe in vivo non-viral gene therapy. Bioelectrochemistry 70, 501-507.

Čegovnik, U. and Novaković, S. (2004) Setting optimal parameters for in vivo electrotransfection of B16F1, SA1, LPB, SCK, L929 and CHO cells using predefined exponentially decaying electric pulses. Bioelectrochemistry 62, 73-82.

Čemažar, M., Jarm, T., Miklavčič, D., Maček-Lebar, A., Ihan, A., Kopitar, N.A., Serša, G. (1998) Effect of electric-field intensity on electropermeabilization and electrosensitivity of various tumor-cell lines in vitro. Electro and Magnetobiology 17, 263-272.

Čemažar, M., Parkins, C.S., Holder, A.L., Chaplin, D.J., Tozer, G.M. and Serša G. (2001) Electroporation of human microvascular endothelial cells: evidence for an anti-vascular mechanism of electrochemotherapy. British Journal of Cancer 84, 565-570.

Danfelter, M., Engstrom, P., Persson, B.R.R. and Salford, L.G. (1998) Effect of high voltage pulses on survival of Chinese hamster V79 lung fibroblast cells. Bioelectrochemistry and Bioenergetics 47, 97-101.

Davalos, R.V., Mir, L.M. and Rubinsky, B. (2005) Tissue ablation with irreversible electroporation. Annals of Biomedical Engineering 33, 223-231.

D’Halluin, K., Bonne E., Bossut M., De Beuckeleer M. and Leemans J. (1992) Transgenic maize plants by tissue electroporation. The Plant Cell 4, 1495-1505. 
Dimitrov, D.S. and Sowers A.E. (1990) A delay in membrane fusion: lag times observed by fluorescence microscopy of individual fusion events induced by an electric field pulse. Biochemistry $29,8337-8344$.

Djuzenova, C.S., Zimmermann, U., Frank, H., Sukhorukov V.L., Richter, E. and Fuhr, G. (1996) Effect of medium conductivity and composition on the uptake of propidium iodide into electropermeabilized myeloma cells. Biochimica et Biophysica Acta 1284, 143-152.

Dower, W.J., Miller, J.F. and Rasdale C.W. (1988) High efficiency transformation of E, coli by high voltage electroporation. Nucleic Acids Research 16, 6127-6145.

Dower, W.J., Chassy, B.M., Trevors, J.T. and Blaschek, H.P. (1992) Protocols for the transformation of bacteria by electroporation. In: D.C. Chang, B.M. Chassy, J.A., Saunders and A.E. Sowers (Eds.), Guide to Electroporation and Electrofusion. Academic Press, San Diego, pp. 265-290.

Edd, J.F., Horowitz, L., Davalos, R.V., Mir, L.M. and Rubinsky, B. (2006) In vivo results of a new focal tissue ablation technique: irreversible electroporation. IEEE Transactions on Biomedical Engineering 53, 1409-1415.

Escande-Geraud, M.L., Rols, M.P, Dupont, M.A., Gas, N. and Teissié J. (1988) Reversible plasma membrane ultrastructural changes correlated with electropermeabilization in Chinese hamster ovary cells. Biochimica et Biophysica Acta 939, 247-259.

Eynard, N., Rols, MP, Ganeva, V., Galutzov, B., Sabri, N. and Teissié J. (1997) Electrotransformation pathways of prokaryotic and eukaryotic cells: recent developments. Bioelectrochemistry and Bioenergetics 44, 103-110.

Eynard, N., Rodriguez, F., Trotard, J. and Teissié J. (1998) Electrooptics studies of Escherichia coli electropulsation: orientation, permeabilization and gene transfer. Biophysical Journal 75, 2567-2596.

Faurie, C., Phez, E., Golzio, M., Vossen, C., Lesbordes, J.C. Delteil, C., Teissié, J. and Rols M.P. (2004) Effect of electric field vectoriality on electrically mediated gene delivery in mammalian cells. Biochimica et Biophysica Acta 1665, 92-100.

Faurie, C., Golzio, M., Phez E., Teissié, J. and Rols M.P. (2005) Electric field induced cell membrane permeabilization and gene transfer: theory and experiments. Eng ineering in Life Science 5, 1-7.

Fear, E.C. and Stuchly, M.A. (1998a) Biological cells with gap junctions in low-frequency electric fields. IEEE Transactions on Biomedical Engineering 45, 856-866.

Fear, E.C. and Stuchly, M.A. (1998b) Modeling assemblies of biological cells exposed to electric fields. IEEE Transactions on Biomedical Engineering 45, 1259-1271.

Ferber, D. (2001) Gene therapy: safer and virus free? Science 294, 1638-1642.

Fiedler, S. and Wirth, R. (1988) Transformation of bacteria with plasmid DNA by electroporation. Analytical Biochemistry 170, 38-44.

Fromm, M.E., Taylor, L.P. and Walbot, V. (1985) Expression of genes transferred into monocot and dicot plant cells by electroporation. Proceedings of the National Academy of Sciences of the United States of America 82, 5824-5828.

Fromm, M.E., Taylor, L.P. and Walbot, V. (1986) Stable transformation of maize after gene transfer by electroporation. Nature 319, 791-793.

Gabriel, B and Teissié, J. (1995a) Spatial compartmentation and time resolution of photooxidation of a cell membrane probe in electropermeabilized Chinese hamster ovary cells. European Journal of Biochemistry 228, 710-718.

Gabriel, B. and Teissié, J. (1995b) Control by electrical parameters of short and long-term cell death resulting from electropermeabilization of Chinese hamster ovary cells. Biochimica et Biophysica Acta 1266, 171-178.

Gabriel, B. and Teissié, J. (1997) Direct observation in the millisecond time range of fluorescent molecule asymetrical interaction with the electropermeabilised cell membrane. Biophysical Journal 73, 2630-2637.

Gabriel, B. and Teissié, J. (1999) Time courses of mammalian cell electropermeabilization observed by millisecond imaging of membrane property changes during the pulse Biophysical Journal 76, 2158-2165. 
Gallo, S.A., Sen, A., Hensen, M.L. and Hui, S.W. (2002) Temperature dependant electrical and ultrastructural characterizations of porcine skin upon electroporation. Biophysical Journal 82, $109-119$.

Ganeva, V., Galutzov, B. and Teissié J. (1995) Electric field mediated loading of macromolecules in intact yeast cells is critically controlled at the wall level. Biochimica et Biophysica Acta 1240, 229-236.

Ganeva, V., Galutzov, B. and Teissié J. (2003) High yield electroextraction of proteins from yeast by flow process. Analytical Biochemistry 315, 77-84.

Ganeva, V., Galutzov, B. and Teissié J. (2004) Flow process for electroextraction of intracellular enzymes from the fission yeast, Schizosacchromyces pombe. Biotechnology Letters 26, 933-937.

Gehl, J., Skovsgaard, T. and Mir, L.M. (2002) Vascular reactions in vivo electroporation: characterization and consequences for drug and gene delivery. Biochimica et Biophysica Acta 1569, $51-58$.

Golzio, M., Mora, M.P., Raynaud, C., Delteil, C., Teissié, J. and Rols M.P. (1998) Control by osmotic pressure of voltage-induced permeabilization and gene transfer in mammalian cells. Biophysical Journal 74, 3015-3022.

Golzio, M., Teissié, J. and Rols M.P. (2002) Direct visualization at the single cell level of electrically mediated gene delivery. Proceedings of the National Academy of Sciences of the United States of America 99, 1292-1297.

Gould, S.W. (1995) Biodeterioration of foods and overview of preservation in the food and dairy industries. International Biodeterioration and Biodegradation 37, 267-277.

Graškova, D., Sigler, K., Jonderova, B. and Plašek, J. (1996) Effect of high-voltage pulses on yeast cells: factors influencing the killing efficiency. Bioelectrochemistry and bioenergetics 39, 195-202.

Grobner, U., Velizarov and S. and Berg, H. (1996) Polylysine supports electrofusion. Bioelectrochemistry and Bioenergetics 39, 181-184.

Gross, D., Loew, L.M. and Webb, W.W. (1986) Optical imaging of cell membrane potential changes induced by applied electric fields. Biophysical Journal 50, 339-348.

Grosse, C. and Schwan, H.P. (1992) Cellular membrane potentials induced by altering fields. Biophysical Journal 63, 1632-1642.

Gurel, F. and Gozukirmizi, N. (2000) Optimization of gene transfer into barley (Hordeum vulgare L.) mature embryos by tissue electroporation. Plant Cell Reports 19, 787-791.

Haas, C.N. and Atrualiye, D.N. (1999) Kinetics of electroporation - assisted chlorination of Giardia muris. Water Research 33, 1761-1766.

Harkin, D.G. and Hay, E.D. (1996) Effects of electroporation on the tubulin cytoskeleton and direct migration of corneal fibroblasts cultured within collagen matrices. Cell Motility and the Cytoskeleton 35, 345-357.

Hamilton, W.A. and Sale, A.J.H. (1967) Effects of high electric fields on microorganisms: II. Mechanisms and action of the lethal effect. Biochimica et Biophysica Acta 148, 789-800.

He, G.Y. and Lazzeri P.A. (1998) Analysis and optimization of DNA delivery into wheat scutellum and Tritodeum inflorescence explants by tissue electroporation. Plant Cell 18, 64-70.

He, G.Y., Lazzeri P.A. and Cannell M.E. (2001) Fertile transgenic plants obtained from tritordeum inflorescences by tissue electroporation. Plant Cell Reports 20, 67-72.

Heller, R., Gibert, R. and Jaroszeski, M. (1999) Clinical application of electrochemotherapy. Advanced Drug Delivery Reviews 35, 119-129.

Hibino, M., Shigemori, M., Itoh, H., Nagayama, K. and Kinosita, K., (1991) Membrane conductance of an electroporated cell analyzed by submicrosecond imaging of transmembrane potential. Biophysical Journal 59, 209-220.

Hibino, M., Itoh H. and Kinosita, K. (1993) Time courses of cell electroporation as revealed by submicrosecond imaging of transmembrane potential. Biophysical Journal 64, 1789-1800.

Jaroszeski, M.J., Gilbert, R., Fallon, P.G. and Heller, R. (1994) Mechanically facilitated cell-cell electrofusion. Biophysical Journal 67, 1574-1581. 
Janmey, P. (1995) Cell membranes and the cytoskeleton. In: R. Lipowsky and E. Sackmann (Eds.), Structure and Dynamics of Membranes, Handbook of Biological Physics. Elsevier, pp. 805-849.

Joersbo, M. and Brunstedt, J. (1991) Electroporation: mechanism and transient expression, stable transformation and biological effects in plant protoplasts. Physiologia Plantarum 81, 256-264.

Kandušer, M., Šentjurc, M., Miklavčič, D. (2006) Cell membrane fluidity related to electroporation and resealing. European Biophysics Journal 35, 196-204.

Kandušer, M., Šentjurc, M., Miklavčič D. (2008) The temperature effect during pulse application on cell membrane fluidity and permeabilization. Bioelectrochemisty in press.

Kanthou, C., Kranjc, S., Serša, G., Tozer, G., Županič, A. and Čemaar, M. (2006) The endothelial cytoskeleton as a target of electroporation-based therapies. Molecular Cancer Therapeutics 5, 3145-3152.

Kim, Y.H., Han, K.S., Oh, S., You, S. and Kim S.H. (2005) Optimization of technical conditions for the transformation of Lactobacillus acidophilus strains by electroporation. Journal of Applied Microbiology 99, 167-174.

Kinosita, K. and Tsong, T.Y. (1977) Formation and resealing of pores of controlled sizes in human erythrocyte membrane, Nature 268, 438-441.

Kinosita, K. and Tsong, T.Y. (1979) Voltage induced conductance in human erythrocyte membranes. Biochimica et Biophysica Acta 554, 479-497.

Kinosita K., Ashikawa, I., Saita, N., Yoshimura, H., Itoh, H., Nagayama, K. and Ikegami, A. (1988) Electroporation of cell membrane visualized under pulsed-laser fluorescence microscope. Biophysical Journal 53, 1015-1019.

Klenchin, V.A., Sukharev, S.I., Serov, S.M., Chernomordik, L.V. and Chizmadzhev, Y.A. (1991) Electrically induced DNA uptake by cells is a fast process involving DNA electrophoresis. Biophysical Journal 60, 804-811.

Kotnik, T., Bobanovič, F. and Miklavčič D. (1997) Sensitivity of transmembrane voltage induced by applied electric fields - a theoretical analysis. Bioelectrochemistry Bioenergetics 43, 285-291.

Kotnik, T. and Miklavčič, D. (2000) Analytical description of transmembrane voltage induced by electric fields on spheroidal cells. Biophysical Journal 79, 670-679.

Kotnik, T., Mir, L.M., Flisar, K., Puc, M. and Miklavčič, D. (2001a) Cell membrane electropermeabilization by symmetrical bipolar rectangular pulses. Part I. Increased efficiency of permeabilization. Bioelectrochemistry 54, 83-90.

Kotnik, T., Miklavčič, D. and Mir, L.M. (2001b) Cell membrane electropermeabilization by symmetrical bipolar rectangular pulses. Part II. Reduced electrolytic contamination. Bioelectrochemistry 54, 91-95.

Kutney, J.P. (1982) Studies in plant tissue culture: potential source of clinically important antitumor agents. Pure and Applied Chemistry 54, 2523-2536.

Ladygin, V.G. (2004) Efficient transformation of mutant cells of Chlamydomonas reinhardtii by electroporation. Process Biochemistry 39, 1685-1691.

Lebovka, N.I., Bazhal, M.I. and Vorobiev, E. (2000) Simulation and experimental investigation of food material breakage using pulsed electric field treatment. Journal of Food Engineering 44, $213-223$

Lebovka, N.I., Bazhal, M.I. and Vorobiev, E. (2002) Estimation of characteristics damage time of food materials in pulsed-electric fields. Journal of Food Engineering 54, 337-346.

Lebovka, N.I. and Vorobiev, E. (2004) On the origin of the deviation from the first-order kinetics in inactivation of microbial cells by pulsed electric fields. International Journal of Food Microbiology 91, 83-89.

Lee, R.C., River P., Pan, F.S., Ji, L. and Wollmann, R.L. (1992) Surfactant-induced sealing of electropermeabilized skeletal muscle membranes in vivo. Proceedings of the National Academy of Sciences of the United States of America 89, 4524-4528.

Lee, R.C. and Dougherty, W. (2003) Electrical injury: mechanisms, manifestations and therapy. IEEE Transactions on Dielectrics and Electrical Insulation 10, 810-819. 
Lee, T.M.O., Turgeon, R. and Wu, R. (1986) Expression of a foreign gene linked to either a plant virus or a Drosophila promoter, after electroporation of protoplasts of rice, wheat and sorghum. Proceedings of National Academy Sciences of the United States of America 83, $6815-6819$.

Leontiadou, H., Mark, A.E. and Marrink, S.J. (2004) Molecular dynamics simulation of hydrophilic pores in lipid bilayers. Biophysical Journal 86, 2156-2164.

Li, L.H., Shivakumar, R., Feller, S., Allen, C., Weiss, J.M., Dzekunov, S., Singh, V., Holaday, J., Fratantoni, J. and Liu, L.N. (2002) High efficient, large volume flow electroporation. Technology in Cancer Research and Treatment 1, 341-349.

Liu, M., Gothe G. and Berg, H. (2000) Electroporation and fusion of human cancer cells modified by amino acids and polypeptides. Electro and Magnetobiology 19, 331-338.

Liu, F., Heston, S., Shollenberger, L.M., Sun, B., Mickle, M., Lovell, M. and Huang L. (2006) Mechanisms of in vivo DNA transport into cells by electroporation: electrophoresis across the plasma membrane may not be involved. The Journal of Gene Medicine 8, 353-361.

Loew, L.M. (1992) Voltage-sensitive dyes: Measurements of membrane potentials induced by DC and AC electric fields. Bioelectromagnetics Supplement 1, 179-189.

Lucas, M.L. and Heller R. (2001) Immunomodulation by electrically enhanced delivery of plasmid DNA encoding IL-12 to murine skeletal muscle. Molecular Therapy 3, 47-53.

Lundqvist, J.A., Sahlin, F., Aberg, M., A.I., Stromberg, A. and Erikson, P.S. (1998) Alterning the biochemical state of individual cultured cells and organelles with ultramicroelectrodes. Proceedings of the National Academy of Sciences of the United States of America 95, 10356-10360.

Maček-Lebar, A., Kopitar, N.A., Ihan, A., Serša, G. and Miklavčič, D. (1998) Significance of treatment energy in cell electropermeabilization. Electro. Magnetobiol. 17, 253-260.

Maček-Lebar, A. and Miklavčič, D. (2001) Cell electropermeabilization to small molecules in vitro: control by pulse parameters. Radiologica Oncology 35, 193-202.

Maccarrone, M., Bladergroen, M..R., Rosato, N. and Agro F. (1995) Role of peroxidation in electroporation induced cell permeability. Biochemical and Biophysical Research Communications 209, 417-425.

Marszalek, P., Liu, D.S. and Tsong, T.Y. (1990) Schwan equation and transmembrane potential induced by altering electric field. Biophysical Journal 58, 1053-1058.

Mason, C.K., Collins, M.A. and Thompson K. (2005) Modified electroporation protocol for Lactobacilli isolated from the chicken crop facilitates transformation and the use of a genetic tool. Journal of Microbial Methods 60, 353-363.

Mazan, M., Mazanova, K. and Farkas, V. (2006) Bukova stena hub - Vyzva pre vyskum novych antimykotik, Chem. Listy 100, 433-439.

Meaking, W.S., Edgerton, J., Wharton, C.W. and Meldrum, R.A. (1995) Electroporation-induced damage in mammalian cell DNA. Biochimica et Biophysica Acta 1264, 357-362.

Mehrle, W., Zimmermann, U. and Hampp, R. (1985) Evidence for asymetrical uptake of fluorescence dyes through electro- permeabilized membranes of Avena mesophyll protoplasts. FEBS Letters 185, 89-94.

Meilhoc, E., Masson, J.M. and Teissie, J. (1990) High efficiency transformation of intact yeast cells by electric field pulses. Biotechnology (N.Y.) 8, 223-227.

Miklavčič, D., Beravs, K., Šemrov, D., Čemaar, M., Demšar, F. and Serša, G. (1998) The importance of electric field distribution for effective in vivo electroporation of tissues. Biophysical Journal 74, 2152-2158.

Miklavčič, D., Šemrov, D., Mekid, H. and Mir, L.M. (2000) A validated model of in vivo electric field distribution in tissues for electrochemotherapy and for DNA electro transfer for gene therapy. Biochimica et Biophysica Acta 1519, 73-83.

Miklavčič, D., Pucihar, G., Pavlovec, M., Ribarič, S., Mali, M., Maček-Lebar, A., Petkovšek, M., Nastran, J., Kranjc, S., Čemaar, M. and Serša, G. (2005) The effect of high frequency electric pulses on muscle contractions and antitumor efficiency in vivo for a potential use in clinical electrochemotherapy. Bioelectrochemistry 65, 121-128. 
Miklavčič, D., Čorović S, Pucihar, G. and Pavšelj, N. (2006a) Importance of tumour coverage by sufficiently high local electric field for effective electrochemotherapy. European Journal of Cancer Supplement 4, 45-51.

Miklavčič, D. and Puc, M. (2006b) Electroporation. In: Wiley Encyclopedia of Biomedical Engineering, John Wiley \& Sons, New York,. pp. 1-11.

Miller, L., Leor, J. and Rubinsky, B. (2005) Cancer cell ablation with irreversible electroporation. Technology in Cancer Research and Treatment 4, 1-7.

Mir, L.M. and Orlovski, S. (1999) Mechanisms of electrochemotherapy. Advanced Drug Delivery $35,107-118$.

Mir, L.M. (2000) Therapeutical perspectives of in vivo cell electropermeabilization. Bioelectrochemistry $53,1-10$.

Mordhorst, A.P. and Lorz, H. (1992) Electrostimulated regeneration of platelets from protoplasts derived from cell suspensions of barley (Hordeum vulgaris). Physiologia Plantarum 85, 289-294.

Neumann, E. and Rosenheck K. (1972) Permeability changes induced by electric impulses in vesicular membranes. Journal of Membrane Biology. 10, 279-290.

Neumann, E., Schafer-Ridder, M., Wang, Y. and Holschneider, P.H. (1982) Gene transfer into mouse lyoma cells by electroporation in high electric fields. The EMBO Journal 1, 841-845.

Neumann, E., Sowers, A.E. and Jordan, C.A. (1989) Electroporation and electrofusion in cell biology, Plenium press, New York.

Neumann, E. (1992) Membrane electroporation and direct gene transfer. Bioelectrochemistry and Bioenergetics 28, 247-267.

Neumann, E., Kakorin, S., Tsoneva, I., Nikolova, B. and Tomov, T. (1996) Calcium mediated DNA adsorption to yeast cells and kinetics of cell transformation by electroporation. Biophysical Journal 71, 868-877.

Neumann, E., Kakorin, S. and Toensing, K. (1999) Fundamentals of electroporative delivery of drugs and genes. Bioelectrochemistry and Bioenergetics 48, 3-16.

Oblak, J., Kriaj, D., Amon, S., Maček-Lebar, A., Miklavčič, D. (2007) Feasibility study for cell electroporation detection and separation by means of dielectrophoresis. Bioelectrochemistry $71,164-171$.

O'Hare, M.J., Ormerod M.G., Imrie P.R., Peacock J.H. and Asche W. (1989) Electropermeabilization and electrosensitivity of different types of mammalian cells. In: E. Neumann, A.E. Sowers and C.A. Jordan (Eds.), Electroporation and Electrofusion in Cell biology, Plenium Press, New York, pp. 319-330.

Ohno-Shosaku, T. and Okada Y., J. (1985) Electric pulse-induced fusion of mouse lymphoma cells: roles of divalent cations and membrane lipid domains. The Journal of Membrane Biology 85, 269-280.

Ochatt, S.J., Rech, E.L., Davey, M.R. and Power, J.B. (1988) Long-term effect of electroporation on enhancement of growth and plant regeneration of colt cherry (Prunus aviun x pseudocerasus) protoplasts. Plant Cell Reports 7, 393-395.

Olofsson, J., Nolkantz, K., Rytsen, F., Lambie, B.A., Weber, S.G., Owar, O. (2003) Single cell electroporation. Current Opinion in Biotechnology 14, 29-34.

Orrenius, S., McConkey, D.J., Bellomo, G. and Nicotera, P. (1989) Role of Ca2 ${ }^{+}$in toxic cell killing, TiPS 10, 281-285.

Pavlin, M., Pavšelj, N. and Miklavčič, D. (2002) Dependance of induced transmembrane potential on cell density, arrangement, and cell position inside a cell system. IEEE Transaction ob biomedical engineering 49, 605-612.

Pavlin, M., Kandušer, M., Reberšek, M., Pucihar, G., Hart, F.X., Madjarević, R. and Miklavčič, D. (2005) Effect of cell electroporation on the conductivity of a cell suspension. Biophysical Journal 88, 4378-4390.

Pavlin, M., Leben, V. and Miklavčič, D. (2007) Electroporation in dense cell suspension Theoretical and experimental analysis of ion diffusion and cell permeabilization. Biochimica et Biophysica Acta 1770, 12-23. 
Pavšelj, N. and Preat, V. (2005a) DNA electro transfer into skin using a combination of one high and one low-voltage pulse. Journal of Controlled Release 106, 407-415.

Pavšelj, N., Bregar, Z., Cukjati, D., Batiuskaite, D., Mir, L.M. and Miklavčič, D. (2005b) The course of tissue permeabilization studied on a mathematical model of subcutaneous tumor in small animals. IEEE Transactions on Biomedical Engineering 52, 1373-1381.

Pitt, R.E., Parks, J.E., Huber, C.S. and Sangree, J.A. (1997) Glycerol permeability of rye protoplasts as affected by temperature and electroporation. Plant, Cell Tissue and Organ Culture 50, 215-219.

Pliquett, U., Gift, E.A. and Weaver, J.C. (1996) Determination of the electric field and anomalous heating caused by exponential pulses with aluminum electrodes in electroporation experiments. Bioelectrochemistry and Bioenergetics 39, 39-53.

Prausnitz, M.R., Lau, B.S., Milano, C.D., Conner, S., Langer, R. and Weaver, J.C. (1993) A quantitative study of electroporation showing a plateau in net molecular transport. Biophysica Journal 65, 414-422.

Prausnitz, M.R., Corbett, J.D., Gimm, J.A., Golan, D.E., Langer, R. and Weaver, J.C. (1995) Millisecond measurement of transport during and after an electroporation pulse. Biophysica Journal 68, 1864-1879.

Prud'homme, G.J., Glinka, Y., Khan, A.S. and Draghia-Akli, R. (2006) Electroporation-enhanced nonviral gene transfer for the prevention or treatment of immunological, endocrine and neoplastic diseases. Current Gene Therapy 6, 243-273.

Puc, M., Kotnik, T., Mir, L.M. and Miklavčič, D. (2003) Quantitative model of small molecules uptake after in vitro cell electropermeabilization. Bioelectrochemistry 60, 1-10.

Puc, M., Čorović, S., Flisar, K., Petkovšek, M., Nastran, J., Miklavčič, D. (2004) Techniques of signal generation required for electropermeabilization. Survey of electropermeabilization devices. Bioelectrochemistry 64, 113-124,

Pucihar, G., Kotnik, T., Kandušer M. and Miklavčič, D. (2001) The influence of medium conductivity on electropermeabilization and survival of cells in vitro. Bioelectrochemistry 54, $107-115$.

Pucihar, G., Mir, L.M., Miklavčič, D. (2002) The effect of pulse repetition frequency on the uptake into electropermeabilized cells in vitro with possible applications in electrochemotherapy. Bioelectrochemistry $57,167-172$.

Pucihar, G., Kotnik, T., Valič, B. and Miklavčič, D. (2006) Numerical determination of transmembrane voltage induced on irregularly shaped cells, Annals of Biomedical Engineering 34, $642-652$.

Pucihar, G., Kotnik, T., Teissié, J. and Miklavčič, D. (2007). Electropermeabilization of dense cell suspensions. European Biophysics Journal 36, 173-185.

Quecini, Y.M., de Oliveira, A.C., Alves, A.C. and Vieira, M.L.C. (2002) Factors influencing electroporation mediated gene transfer to Stylosantehes guianensis (Abul.) SW. protoplasts. Genetics and Molecular Biology 25, 73-80.

Rakoczy-Trojanowska, M. (2002) Aletrnative methods of plant transformation - A short review. Cellular and Molecular Biology Letters 7, 849-858.

Ramos, C. and Teissié, J. (2000a) Electrofusion: a biophysical modification of cell membrane and a mechanism in exocytosis. Biochimie 82, 511-518.

Ramos, C. and Teissié, J. (2000b) Tension-voltage relationship in membrane fusion and its implication in exocytosis. FEBS Letters 465, 141-144.

Reberšek, M., Faurie, C., Kandušer, M., Čorović, S., Teissie, J., Rols M.P., Miklavčič, D. (2007) Electroporator with automatic change of electric field direction improves gene electrotransfer in vitro. Biomedical Engineering OnLine 6, 25

Rech, E.L., Ochatt, S.J., Chand, P.K., Davey, M.R. , Mulligan, B.J. and Power, J.B. (1988) Electroporation induces DNA synthesis in cultured plant protoplasts. Biotechnology 6, 1091-1093.

Rech, E.L., Ochatt, S.J., Chand, P.K., Power, J.B. and Davey M.E. (1987) Electro-enhancement of division of plant protoplast derived cells. Protoplasma 141, 169-176. 
Rols, M.P. and Teissié, J. (1989) Ionic strength modulation of electrically induced permeabilization and associated fusion of mammalian cells. European Journal of Biochemistry 179, 109-115.

Rols, M.P. and Teissié, J. (1990a) Electropermeabilization of mammalian cells. Quantitative analysis of the phenomenon. Biophysical Journal 58, 1089-1098.

Rols, M.P. and Teissié, J. (1990b) Modulation of electrically induced permeabilization and fusion of Chinese hamster ovary cells by osmotic pressure. Biochemistry 29, 4561-4567.

Rols, M.P., Dahhou, F., Mishra, K.P. and Teissié, J. (1990c) Control of electric field induced cell membrane permeabilization by membrane order. Biochemistry 29, 2960-2966.

Rols, M.P. and Teissié, J. (1992a) Experimental evidence for the involvement of the cytoskeleton in mammalian cell electropermeabilization. Biochim Biophys Acta 1111, 45-50.

Rols, M.P., Coulet D. and Teissié J. (1992b) Highly efficient transfection of mammalian-cells by electric-field pulses - application to large volumes of cell-culture by using a flow system European Journal of Biochemistry 206, 115-121.

Rols, M.P. (2006) Electropermeabilization, a physical method for the delivery of therapeutic molecules into cells. Biochimica et Biophysica Acta 1758, 423-428.

Rouan, D., Montane, M.H., Alibert, G. and Teissié J. (1991) Relationship between protoplast size and critical field strength in protoplast electropulsing and application to reliable DNA uptake in Brassica. Plant Cell Reports 10, 139-143.

Rubinsky, B., Onik, G. and Mikus, P. (2007) Irreversible electroporation: a new ablation modalityclinical implications. Technology in Cancer Research and Treatment 6, 37-48.

Ryttsen, F., Farre, C., Brennan, C., Weber, S.G., Nolkrantz, K., Jardemark, K., Chiu, D. and Orwar, O. (2000) Characterization of single-cell electroporation by using patch-clamp and fluorescence microscopy. Biophysical Journal 79, 1993-2001.

Sabri, N., Pelissier, B. and Teissié J. (1996a) Transient and stable electrotransformation of intact black Mexican sweet maize cells are obtained after preplasmolysis. Plant Cell Reports 15, 924-928.

Sabri, N., Pelissier, B. and Teissié, J. (1996b) Electropermeabilization of intact maize cells induces an oxidative stress. European Journal of Biochemistry 238, 737-743.

Sabri, N., Pelissier, B. and Teissié, J. (1998) Ascorbate increases electrotransformation efficiency of intact maize plants. Analytical Biochemistry 264, 284-286.

Sale, A.J.H., and Hamilton W.A. (1967) Effects of high electric fields on microorganisms. I Killing of bacteria and yeast. Biochimica et Biophysica Acta 148, 781-788.

Saunders, J.A., Roskos, L.A., Mischke, S., Aly, M.A.M. and Owens L.D. (1986) Behaviour and viability of tobacco protoplasts in response to electrofusion parameters. Plant Physiology. 80, $117-121$.

Saunders, J.A., Matthewas, B.F. and Miller, P.D. (1989) Plant gene transfer using electrofusion and electroporation. In: E. Neumann, A.E. Sowers and C.A. Jordan (Eds.), Electroporation and Electrofusion in Cell Biology, Plenium Press, New York, pp. 319-330.

Saunders, J.A., Lin, C.H., Hou, B.H., Cheng, J., Tsengawa, N., Lin, J.J., Smith, C.R., McIntosh, M.S. and Wert, S.V. (1995) Rapid optimization of electroporation conditions for plant cells, protoplasts, and pollen. Molecular Biotechnology 3, 181-190.

Schaffer, C. and Messner, P. (2005) The structure of secondary cell wall polymers: How Grampositive bacteria stick their cell walls together. Microbiology 151, 643-651.

Serša, G., Čemaar, M. and Miklavčič, D. (1995) Antitumor effectiveness of electrochemotherapy with cis-diamminedichloroplatinum(II) in mice. Cancer Research 55, 3450-3455.

Serša, G., Čemaar, M., Šemrov, D. and Miklavčič D. (1996) Changing electrode orientation improves the efficacy of electrochemotherapy of solid tumors in mice. Bioelectrochemistry and Bioenergetics 39, 61-66.

Serša, G., Štabuc, B., Čemaar, M., Jančar, B., Miklavčič, D. and Rudolf, Z. (1998) Electrochemotherapy with cisplatin: Potentiation of local cisplatin antitumor effectiveness by application of electric pulses in cancer patients. European Journal of Cancer 34, 1213-1218.

Serša, G., Čemaar, M., Miklavčič, D. and Chaplin, D.J. (1999) Tumor blood flow modifying effect of electrochemotherapy with bleomycin. Anticancer Research 19, 4017-4022. 
Serša, G., Krzič, M., Šentjurc, M., Ivanusa T, Beravs, K., Kotnik V., Coer, A., Swartz, J. and Čemaar, M. (2002) Reduced blood flow and oxygenation in SA-1 tumors after electrochemotherapy with cisplatin. British Journal of Cancer, 87, 1047-1054.

Serša, G., Čemaar, M. and Rudolf Z. (2003) Electrochemotherapy: advantages and drawbacks in treatment of cancer patients. Cancer Therapy 1, 133-142.

Somiari, S., Glasspool-Malone, J., Drabick, J., Gilbert, R.A., Heller, R., Jaroszeski, M.J. and Malone, R.W. (2000) Theory and in vivo application of electroporative gene delivery. Molecular Therapy 2, 178-187.

Sorokin, A.P., Ke, X.Y., Chen, D.F. and Elliott, N.C. (2000) Production of fertile transgenic plants via tissue electroporation. Plant Science 156, 227-233.

Sukharev, S.I., Klenchin, V.A., Serov, S.M., Chernomordik, L.V. and Chizmadzhev Y.A. (1992) Electroporation and electrphoretic DNA transfer into cells. The effect of DNA interaction with electropores. Biophysical Journal 63, 1320-1327.

Sowers, A.E (1986) A long -lived fusogenic state is induced in erythrocyte ghosts by electric pulses. J Cell Biol 102, 1358-1362.

Suga M., Goto, A. and Hatakeyama, T. (2007) Electrically induced protein release from Schizosaccharomyces pombe cells in a hyperosmotic condition during and following a high electropulsation. Journal of Bioscience and Bioengineering 103, 298-302.

Susil, R., Šemrov, D. and Miklavčič, D. (1998) Electric field induced transmembrane potential depends on cell density and organization. Electro- and Magnetobiology 17, 391-399.

Stenger, D.A.and Hui, S.W. (1986) Kinetics of ultrastructural changes during electrically-induced fusion of human erythrocytes. The Journal of Membrane Biology 93, 43-53.

Stopper, H., Jones, H. and Zimmermann, U. (1987) Large scale transfection of mouse L-cells by electropermeabilization. Biochimica. et Biophysica Acta 900, 38-44.

Šatkauskas, S., Bureau, M.F., Puc, M., Mahfoudi, A., Scherman, D., Miklavčič, D. and Mir, L.M. (2002) Mechanisms of in vivo DNA electro transfer, Respective contributions of cell electropermeabilization and DNA electrophoresis. Molecular Therapy 5, 1-8.

Šatkauskas, S., Andre, F., Bureau, M.F., Scherman, D., Miklavčič, D. and Mir, L.M. (2005) Electrophoretic component of electric pulses determines the efficacy of in vivo DNA electro transfer. Human Gene Therapy 16, 1194-1201.

Šel, D., Cukjati, D., Batiuskaite, D., Slivnik, T., Mir, L.M. and Miklavčič D. (2005) Sequential finite element model of tissue electropermeabilization. IEEE Transections on biomedical engineering 52, 816-827.

Šel, D., Maček-Lebar, A. and Miklavčič D. (2007) Feasibility of employing model-based optimization of pulse amplitude and electrode distance for effective tumor electropermeabilization. IEEE Transections on biomedical engineering 54, 773-781.

Šemrov, D. and Miklavčič, D. (1998) Calculation of the electrical parameters in electrochemotherapy of solid tumours in mice. Computers in Biology and Medicine 28, 439-448.

Šemrov, D. and Miklavčič, D. (2000) Numerical modeling for in vivo electroporation. In: M.J. Jaroszeski, R. Heller and R. Gilbert (Eds.), Electrochemotherapy, Electrogenetherapy, and Transdermal Drug Delivery, Electrically Mediated Delivery of Molecules to Cells, Methods in Molecular Medicine, 37, Humana Press, New Jersy, pp. 63-81.

Teissié, J. (1988) Effects of electric fields and currents on living cells and their potential use in biotechnology: a survey. Bioelectrochemistry and Bioenergetics 20, 133-142.

Teissié, J., Knutson, V.P., Tsong T.Y. and Lane M.D. (1982) Electric pulse-induced fusion of 3T3 cells in monolayer culture. Science 216, 537-538.

Teissié, J., and Rols, M.P. (1986) Fusion of mammalian cells in culture is obtained by creating the contact between cells after their electropermeabilization. Biochemical and Biophyscal Research Communications 140, 258-266.

Teissié, J. and Conte, P. (1988 a) Electrofusion of large volumes of cells in culture. Part I Anchorage-dependant strains. Bioelectrochemistry and Bioenergetics 19, 49-57.

Teissié, J. and Rols, M.P. (1988 b) Electerofusion of large volumes of cell culture. Part II. Cells growing in suspension. Bioelectrochemistry and Bioenergetics 19, 59-66. 
Teissié, J. and Rols, M.P. (1993) An experimental evaluation of the critical potential difference inducing cell membrane electropermeabilization. Biophysical Journal 65, 409-413.

Teissié, J. and Rols, M.P., (1994) Manipulation of the cell cytoskeleton affects the lifetime of cell membrane electropermeabilization. Annals New York Academy of Sciences USA 720, 98-109.

Teissié, J. and Ramos, C. (1998) Correlation between electric field pulse induced long-lived permeabilization and fusogenecy in cell membrane Biophysical Journal 74, 1889-1898.

Teissié, J., Eynard, N., Gabriel, B. and Rols, M.P. (1999) Electropermeabilization of cell membranes. Advanced drug Delivery Reviews 35, 3-19.

Teissié, J., Eynard, N., Vernhes, M.C., Benichou, A., Ganeva, V., Galutzov, B. and Cabanes, P.A. (2002) Recent biotechnological developments of electropulsation: A prospective review. Bioelectrochemistry 55, 107-112.

Tekle, Astumian, R.D. and Chock, P.B. (1990) Electro-permeabilization of cell membranes: effect of resting membrane potential. Biochemical and Biophysical Research Communications 172, 282-287.

Tekle, Astumian, R.D. and Chock, P.B. (1991) Electroporation by using bipolar oscillating electric field: and improved method for DNA transfection of NIH 3T3 cells. Proceedings of the National Academy of Sciences of the United States of America 88, 4230-4234.

Trevors, J.T., Chassy, B.M., Dower, W.J. and Blaschek, H.P. 1992 Electrotransformation of bacteria by plasmid DNA. In: D.C.Chang, B.M. Chassy, J.A. Saunders and A.E. Sowers (Eds), Guide to Electroporation and Electrofusion, Academic Press, San Diego, pp. 265-290.

Tryfona, T. and Bustard, M.T. (2005) Enhancement of bimolecular transport by electroporation: A review of theory and potential application to transformation of Corynobacterium glutamicum. Biotechnology and Bioengineering 93, 413-423.

Tsong, T.Y. (1991) Electroporation of cell membranes. Biophysical Journal 60, 297-306.

Uemura, K. and Isobe, S. (2002) Developing a new apparatus for inactivating Escherichia coli in saline water with high electric field AC. Journal of Food Engineering 53, 203-207.

Valič, B., Golzio, M., Pavlin, M., Schatz, A., Faurie, C., Gabriel, B., Teissié, J., Rols, M.P., and Miklavčič, D. (2003) Effects of electric field induced transmembrane potential on spheroidal cells: theory and experiment. European Biophysics Journal 32, 519-528.

Valič, B., Pavlin, M. and Miklavčič, D. (2004) The effect of resting transmembrane voltage on cell electropermeabilization: a numerical analysis. Bioelectrochemistry 63, 311-315.

Vanisree, M., Lee, C.Y., Lo, S.F., Nalawade, S.M., Lin, C.Y., and Tsay, H.S. (2004) Studies on the production of some important secondary metabolites from medicinal plants by plant tissue cultures. Bot. Bull. Acad. Sin. 45, 1-22.

Van der Rest, M.E., Lange, C. and Molenaar, D. (1999) A heat shock following electroporation induces highly efficient transformation of Corynebacterium glutamicum with xenogenic plasmid DNA. App Microbiol Biotechnol 52, 541-545.

Velizarov, S. and Berg, H. (1998a) Electropermeabilization and electrofusion of human lymphoma cells modified by proteolytic enzymes. Bioelectrochemistry 46, 263-265,

Velizarov, S., Reitz, M., Gluck, B. and Berg H. (1998b) Electropermeabilization and electrofusion of human cells modified by anesthetic agents. Bioelectrochemistry 47, 89-96.

Vernhes, M.C., Cabanes, P.A. and Teissié, J. (1999) Chinese hamster ovary cell sensitivity to localized electrical stresses. Bioelectrochemistry and Bioenergetics 48, 17-25.

Vienken, J. and Zimmermann, U. (1985) An improved electrofusion technique for production of mouse hybridoma cells. FEBS Letters 182, 278-280.

Wang, X., Hones, I. and Berg, H. (1998) Uptake of sensitizer by electroporated yeast cells. Bioelectrochemistry and bioenergetics $47,175-177$.

Wards, B.J. and Collins, D.M. (1996) Electroporation at elevated temperatures substantially improves transformation efficiency of slow-growing mycobacteria. FEMS Microbiology Letters 145, 101-105.

Walden, R. and Wingender, R. (1995) Gene transfer and plant regeneration techniques, TIBTECH 13, 324-331. 
Weaver, J.C. and Chizmadzhev, Y.A. (1996) Theory of electroporation. Bioelectrochemistry and Bioenergetics 41, 135-160.

Wolf, H., Rols, M.P., Boldt, E., Neumann, E. and Teissié J. (1994) Control by pulse parameters of electric field mediated gene transfer in mammalian cells. Biophysical Journal 66, 524-531.

Wu, F.S. and Feng, T.Y. (1999) Delivery of plasmid DNA into intact plant cells by electroporation of plamolysed cells. Plant Cell Reports 18, 381-386.

Wu, Y., Montes, J.G. and Sjodin, R.A. (1992) Determination of electric field threshold for electrofusion of erythrocyte ghosts. Comparison of the pulse-first and contact-first protocols. Biophysical Journal 61, 810-815.

Xie, T.D., Sun, L. and Tsong, T.Y. (1990) Study of mechanisms of electric field-induced DNA transfection. I DNA entry by surface binding and diffusion through membrane pores. Biophysical Journal 58, 13-19.

Xie, T.D. and Tsong, T.Y. (1992) Study of mechanisms of electric field-induced DNA transfection. II Electric parameters and other conditions for effective transfection. Biophysical Journal 63, 28-34.

Xie, T.D., Sun, L., Zhao, H.G., Fuchs, J.A. and Tsong, T.Y. (1992) Study of mechanisms of electric field-induced DNA transfection. IV Effects of DNA topology on cell uptake and transfection efficiency. Biophysical Journal 63, 1026-1031.

Xue, G.P., Johnson, J.S. and Dalrymple, B.P. (1999) High osmolarity improves the electrotransformation efficiency of the gram-positive bacteria Bacilus subtilis and Bacillus licheniformis. Journal of Microbiological Methods 34, 183-191.

Yang, R.Y.K. and Bayraktar, H.T.P. (2003) Plant cell bioreactors with simultaneous electropermeabilization and electrophoresis. Journal of Biotechnology 100, 13-22.

Zaharoff, D.A., Barr, R.C., Li, C.Y. and Yuan, F. (2002) Electromobility of plasmid DNA in tumor tissues during electric field-mediated gene delivery. Gene Therapy 9, 1286-1290.

Zaharoff, D.A. and Yuan, F. (2004) Effects of pulse strength and pulse duration on in vivo DNA electromobility. Bioelectrochemistry 62, 37-45.

Zampaglione, I, Arcuri, M., Cappelletti, M., Perretta, G., Nicosia, A., La Monica, N. and Fattori, E. (2005) In vivo DNA gene electro-transfer, a systematic analysis of different electrical parameters. The Journal of Gene Medicine 7, 1475-1481.

Zhang, Q., Barosa-Canovas, V. and Swanson, B.G. (1995) Engineering aspects of pulsed electric field pasteurization. Journal of Food Engineering 25, 261-281.

Zhou, A., Liu, M., Baciu, C., Gluck, B. and Berg, H. (2000) Membrane electroporation increases photodynamic effects. Journal of Electroanalytical Chemistry 486, 220-224.

Zimmermann, U. (1982) Electric field-mediated fusion and related electrical phenomena. Biochimica et Biophysica Acta 696, 227-277.

Županič, A., Ribarič, S. and Miklavčič, D. (2007) Increasing the repetition frequency of electric pulse delivery reduces unpleasant sensations that occur in electrochemotherapy. Neoplasma 54, 246-250. 